University of Wollongong

Research Online

Sydney Business School - Papers

Faculty of Business

$1-1-2018$

\title{
Turning information quality into firm performance in the big data economy
}

Samuel Fosso Wamba

Toulouse Business School, samuel.fosso.wamba@neoma-bs.fr

Shahriar Akter

University of Wollongong, sakter@uow.edu.au

Laura Trinchera

NEOMA Business School

Marc De Bourmont

NEOMA Business School

Follow this and additional works at: https://ro.uow.edu.au/gsbpapers

Part of the Business Commons

\section{Recommended Citation}

Fosso Wamba, Samuel; Akter, Shahriar; Trinchera, Laura; and De Bourmont, Marc: Turning information quality into firm performance in the big data economy 2018, 1-28.

https://ro.uow.edu.au/gsbpapers/536

Research Online is the open access institutional repository for the University of Wollongong. For further information contact the UOW Library: research-pubs@uow.edu.au 


\title{
Turning information quality into firm performance in the big data economy
}

\begin{abstract}
Purpose: Big data analytics (BDA) increasingly provide value to firms for robust decision making and solving business problems. The purpose of this paper is to explore information quality dynamics in big data environment linking business value, user satisfaction and firm performance.

Design/methodology/approach: Drawing on the appraisal-emotional response-coping framework, the authors propose a theory on information quality dynamics that helps in achieving business value, user satisfaction and firm performance with big data strategy and implementation. Information quality from BDA is conceptualized as the antecedent to the emotional response (e.g. value and satisfaction) and coping (performance). Proposed information quality dynamics are tested using data collected from 302 business analysts across various organizations in France and the USA.

Findings: The findings suggest that information quality in BDA reflects four significant dimensions: completeness, currency, format and accuracy. The overall information quality has significant, positive impact on firm performance which is mediated by business value (e.g. transactional, strategic and transformational) and user satisfaction.
\end{abstract}

Research limitations/implications: On the one hand, this paper shows how to operationalize information quality, business value, satisfaction and firm performance in BDA using PLS-SEM. On the other hand, it proposes an REBUS-PLS algorithm to automatically detect three groups of users sharing the same behaviors when determining the information quality perceptions of BDA.

Practical implications: The study offers a set of determinants for information quality and business value in BDA projects, in order to support managers in their decision to enhance user satisfaction and firm performance.

Originality/value: The paper extends big data literature by offering an appraisal-emotional responsecoping framework that is well fitted for information quality modeling on firm performance. The methodological novelty lies in embracing REBUS-PLS to handle unobserved heterogeneity in the sample.

\section{Disciplines}

Business

\section{Publication Details}

Fosso Wamba, S., Akter, S., Trinchera, L. \& De Bourmont, M. (2019). Turning information quality into firm performance in the big data economy. Management Decision, 57 (8), 1756-1783. 


\section{Turning Information Quality into Firm Performance in Big Data Economy}

\section{Purpose}

Big data analytics (BDA) increasingly provide value to firms for robust decision making and solving business problems. This paper explores information quality dynamics in big data environment linking business value, user satisfaction and firm performance.

\section{Design/Methodology/Approach}

Drawing on appraisal-emotional response-coping framework, we propose a theory on information quality dynamics that helps in achieving business value, user satisfaction and firm performance with big data strategy and implementation. Information quality from BDA is conceptualized as the antecedent to the emotional response (e.g., value and satisfaction) and coping (performance). Proposed information quality dynamics are tested using data collected from 302 business analysts across various organizations in France and the US.

\section{Findings}

Our findings suggest that information quality in BDA reflects four significant dimensions: completeness, currency, format and accuracy. The overall information quality has significant, positive impact on firm performance which is mediated by business value (e.g., transactional, strategic and transformational) and user satisfaction.

\section{Research limitations/implications}

The paper shows how to operationalize information quality, business value, satisfaction and firm performance in BDA using PLS-SEM. In addition, the papers offers REBUS-PLS algorithm to automatically detect three groups of users sharing the same behaviors when determining the information quality perceptions of BDA.

\section{Practical implications}

The study offers a set of determinants for information quality and business value in big data analytics project, that offers a decision support to managers to enhance user satisfaction and firm performance.

\section{Originality/value}

The paper extends big data literature by offering the appraisal-emotional response-coping framework for modelling information quality on firm performance. The methodological novelty lies in embracing REBUS-PLS to handle unobserved heterogeneity in the sample.

\section{Keywords}

Big data analytics, business value, user satisfaction, firm performance, REBUS PLS 


\section{INTRODUCTION}

Big data has emerged as a new frontier for business in either establishing competitive advantages or exploiting the untapped opportunities(Goes, 2014). In every part of the world, every industry collects more data than ever before, yet is also seeking smarter business strategies to harness this big data revolution. The extant literature identifies 'big data' as "the next management revolution"(A. McAfee \& E. Brynjolfsson, 2012); "the new raw material for business" (Economist, 2010); or "the new science that holds the answers" (Gelsinger, 2012). This increased attention both in the academic and practitioner literature is rooted in the fact that big data analytics enable better understanding of business, markets and consumers; higher productivity linked with profitability; and improved performance measurement mechanisms (Lavalle, Lesser, Shockley, Hopkins, \& Kruschwitz, 2011; A. McAfee \& E. Brynjolfsson, 2012; Verbraken, Lessmann, \& Baesens B., 2012), which are constantly reflected in Google, Amazon, Harrah's, Capital One, and Netflix's business models. With the objective of leapfrogging competition, companies are increasingly interested in big data analytics (hereinafter called BDA) to transform their business models by customizing what consumers want, when they want it, how many they want, and what incentives will make them want more in their lifetime (Thomas H Davenport, 2006). However, despite the widespread buzz around BDA, leveraging BDA-driven information to generate business value continues to be a challenge for many organizations. To cope with these challenges, consulting firms, such as Gartner, IBM, and McKinsey \& Co. have started providing services to help firms capitalize on this opportunity. The extant literature highlights that, "[a]s big data evolves, the architecture will develop into an information ecosystem: a network of internal and external services continuously sharing information, optimizing decisions, communicating results and generating new insights for businesses"(T. H. Davenport, P. Barth, \& R. Bean, 2012). However, there are growing concerns and confusion regarding analytics-driven 
information quality (IQUL), business value (BVAL), user satisfaction (USAT), and firm performance (FPER) (T. H. Davenport et al., 2012; Goes, 2014). Clearly, owing to a paucity of research in this spectrum, a better understanding of IQUL dynamics is required in order to address the research gap. Because, "[w]hile generating quality information is the primary purpose of any IS [information system], few studies have explored the variables that affect Information Quality. This is a significant gap in the IS research. Quality information is a foundation of good decision making and positive outcomes, yet we know little about the variables that lead to improved Information Quality. More research is needed in order to understand better how to influence Information Quality"(Stacie Petter, DeLone, \& McLean, 2013,p.30).

Our objective in this article is twofold. First, we investigate ways to leverage IQUL in BDA to achieve enhanced FPER by proposing and testing a theory from the perspective of managers/users. This perspective is put in this context because FPER ultimately depends on managers who are the most critical stakeholder in terms of their interest in knowing more about their businesses by translating big data into better information and improved decisions (A. McAfee \& E. Brynjolfsson, 2012). The study also focuses on managers because they have the greatest curiosity about unlocking the power of big data for large-scale interventions and predictions (Thomas H. Davenport, 2012; Lavalle et al., 2011). We also examine the managers' perspective because they want to understand "how to fish out answers to important business questions from today's tsunami of unstructured information" (Thomas H Davenport \& Patil, 2012,p.73). Despite the importance of analytics-driven IQUL and its impact on USAT, BVAL and FPER, little research on manager-side BDA has focused on such dynamics. To fill this knowledge gap, we propose a conceptual model which is rooted in the traditional appraisal processes (IQUL, BVAL)-emotional reactions (USAT)-coping responses (FPER) framework (Bagozzi, 1992; Lazarus, 1991). In developing our theoretical model, we 
propose that analytics-driven information quality and business value appraisal processes lead to emotional responses (managers' satisfaction), which, in turn, induce coping activities in terms of increasing the target outcomes, that is, firm performance. To empirically test the proposed relationships, we analysed data from 302 managers who rely on BDA for their dayto-day operations and strategic directions across various industries in the USA and France. The study findings suggest that analytics-driven IQUL has a positive impact on BVAL and USAT which again influences FPER.

Second, we attempt to provide insights on unobserved heterogeneity in our sample whilst investigating their perceptions of IQUL-BVAL-USAT and FPER. Because, it is unrealistic to assume that empirical studies are based on homogeneous sample representing a single population in the social and behavioral sciences, such as e-commerce (Becker, Rai, Ringle, \& Völckner, 2013). Indeed, unobserved groups might represent significant heterogeneity in data, thus leading to bias parameter estimates and invalid statistical conclusions (Jedidi, Jagpal, \& DeSarbo, 1997). Working with unobserved heterogeneity means finding groups of units or clusters having similar behaviours. We used the REBUS-PLS algorithm (Esposito Vinzi, Trinchera, Squillacciotti, \& Tenenhaus, 2008) to investigate the presence of unobserved heterogeneity in our sample. REBUS-PLS algorithm has been designed to detect homogenous groups of units with increased predictive power. The differences between model parameter estimates are analysed for significance testing by means of multi-group comparison (Wynne W Chin \& Dibbern, 2010).

In putting forward the theory of manager-side BDA strategy, this study extends this research stream in multiple ways. Our study contributes to the big data literature by exploring the impact of BDA on business strategy with regard to IQUL-BVAL-USAT-FPER (Goes, 2014; Sharma, Mithas, \& Kankanhalli, 2014). The extant research has largely focused on anecdotal evidence in proposing BDA strategy (D. Barton \& D. Court, 2012; A. McAfee \& E. 
Brynjolfsson, 2012; Shanks, Bekmamedov, \& Sharma, 2011; Shanks \& Bekmamedova, 2012). We contribute to this research by examining the practical relationships between BDAdriven IQUL and BVAL (Thomas H. Davenport, 2010; Forrester, 2012; Kiron \& Shockley, 2011; Lavalle et al., 2011). Furthermore, this study seeks to build on the extant research by investigating IQUL as it relates to BDA and influences USAT and FPER. Methodologically, the application of REBUS-PLS in exploring unobserved heterogeneity provides critical insights on differences among segments in the sample and facilitates theory development by adding additional descriptions on different groups of managers' perceptions regarding IQULBVAL-USAT-FPER dynamics (Becker et al., 2013). The research questions of the study are:

How do IQUL perceptions of BDA determine critical business outcomes?

Do existing groups of users share the same behaviors (in terms of strength of the effects) when determining the IQUL perceptions of BDA? And if yes, how different are they?

The answer to these research questions clearly contributes to the business-technologyanalytics alignment of global organizations by framing the impact of IQUL on individual and business outcomes. The organization of this paper is as follows: the next section focuses on the conceptual model and hypotheses development. This is followed by the method and findings. The last section focuses on the study's theoretical and practical contributions and provides guidelines for future research.

\section{RESEARCH MODEL}

The proposed conceptual model on BDA illuminates IQUL as the core concept that enhances BVAL and USAT, which, in turn, influences FPER within an organization. The focus on analytics-driven IQUL to establish a linkage between BVAL, USAT, and FPER is based on the fact that "[b]ig data still aims in large part to deliver the right information to the right 
person at the right time in the right form, but is now able to do so in a significantly more sophisticated form"(Agarwal \& Dhar, 2014,p.447). Using a coordination perspective ${ }^{1}$, the study proposes that analytics driven information quality across multiple digital platforms enhances business value which is required to increase satisfaction and overall firm performance. This investigation of manager-side BDA strategy is set in analytics-driven organizations across various industries. The conceptual model draws from the IS and services marketing literature, thus enabling the interdisciplinary approach that is required to tackle the challenges and opportunities in BDA (Agarwal \& Dhar, 2014; Goes, 2014). Figure 1 shows the research model and Table 1 defines the constructs in the model.

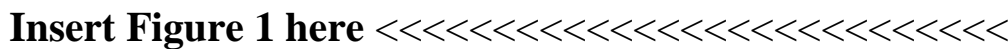

\section{Defining Big Data Analytics}

Big data refers to the huge quantities of transaction, clickstream, voice and video data (T. H. Davenport et al., 2012). In defining big data, Schroeck et al. (2012) identified its various dimensions including greater scope of information; real-time information; new kinds of data and analysis; non-traditional forms of media data; new technology-driven data; large volumes of data; the latest buzzword; and social media data. In defining big data, IBM (2012), Johnson (2012), and Davenport et al. (2012) focus more on the aspect of the variety of data sources, while other authors, such as Rouse (2011), Fisher et al. (2012), Havens et al. (2012), and Jacobs (2009), emphasize the storage and analysis required when dealing with 'big data'. IDC (2013) defines 'big data' by focusing on three main characteristics: the data itself, the analytics of the data, and presentation of the results of the analytics that allow business value creation in terms of new products or services.

\footnotetext{
${ }^{1}$ Coordination theories assess patterns of interactions across multiple platforms to influence the structure of activities within organizations (Malone and Crowston 1994).
} 
Boyd and Crawford (2012) propose a more holistic definition of 'big data' that entails: technology (e.g., storage, computation power), analysis (e.g., patterns identification for economic, social, technical, and legal claims), and mythology (e.g., the widespread belief that 'big data' offers a higher level ability to generate valuable insights) (p. 663). Based on the above definitions of big data, it is clear that the extant literature conceptualizes BDA from different perspectives. Dijcks (2012) reports that BDA, through the use of statistical analysis and data mining, have the ability to manage a large scale of data and provide faster response times as a result of changes in customer behavior, and, above all, it can mechanize decisions based on analytical models. To define BDA, studies also focus on strategy-led analytics, or analytics that create sustainable value for business. For example, Lavalle et al. (2011) explain that the application of business analytics (or the ability to use big data) for decision making must essentially be connected with the firm's strategy. Indeed, strategy-driven analytics have received a significant amount of attention owing to definitions that refer to their role in better decision making. Studies also focus on 'competitive advantages' and 'differentiation' while applying business analytics to analyze real-time data (Schroeck et al., 2012). We define BDA as a holistic process that involves the collection, analysis, use, and interpretation of data for various functional divisions, with a view to gaining actionable insights, creating business value, and establishing competitive advantages.

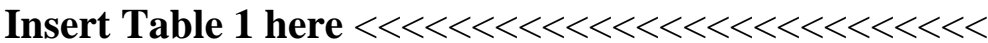

\section{Information Quality}

Drawing on coordination theories ${ }^{2}$ (Crowston, 1997; Malone \& Crowston, 1990; Setia, Venkatesh, \& Joglekar, 2013), this study proposes that BDA use various sources of data in providing business information in order to identify and assess patterns that are based on

\footnotetext{
${ }^{2}$ Coordination theories, characterized by Crowston (1997, p. 159), are a still developing body of "theories about how coordination can occur in diverse kinds of systems" (Malone and Crowston 1994, p. 87).
} 
diverse actors. This diversity of data was highlighted in big data literature as, "[i]ndeed, companies that learn to take advantage of big data will use real-time information from sensors, radio frequency identification and other identifying devices to understand their business environments at a more granular level, to create new products and services, and to respond to changes in usage patterns as they occur"'(T. H. Davenport et al., 2012). Indeed, BDA enable the coordination of data from a variety of fields to improve information quality and organizational performance. Following the arguments of coordinator theories (e.g.,Malone \& Crowston, 1994), this study contends that complex and interdependent BDA platforms produce information in coordination that enhances BVAL, USAT, and FPER.

The extant research assessing the organizational impacts of BDA highlights the importance of IQUL in these environments (Thomas H Davenport, 2006; Schläfke, Silvi, \& Möller, 2013). The application of BDA-driven quality information, rather than gut instinct, in decision making has become a core focus of research after evidence of the success of FPER in many organizations (Lavalle et al., 2011; A. McAfee \& E. Brynjolfsson, 2012). The extant literature identifies that IQUL influences various outcomes, such as satisfaction (Nelson, Todd, \& Wixom, 2005; Xu, Benbasat, \& Cenfetelli, 2013); loyalty (Zhou, Lu, \& Wang, 2009); trust in the IT artifact (Vance, Elie-Dit-Cosaque, \& Straub, 2008); and user and knowledge-sharing behavior (Durcikova \& Gray, 2009). We propose that IQUL is a critical component of a firm's BDA success (DeLone \& McLean, 1992; Barbara H Wixom \& Todd, 2005). The ultimate managerial challenge in the BDA environment lies in finding patterns in data and translating them into useful business information as mentioned in big data literature, "[b]ut to compete on that information, companies must present it in standard formats, integrate it, store it in a data warehouse, and make it easily accessible to anyone and everyone" (Thomas $\mathrm{H}$ Davenport, 2006). 
The extant literature identifies four characteristics of information, namely, completeness, accuracy, format, and currency that are often emphasized (see Table 1). These attributes may differ across BDA environments; however, the degree of completeness, accuracy, format, and currency of information significantly contributes to the quality of information perception of managers across organizations. For instance, BDA used in a bank may provide employees with a 360-degree view of more complete information by combining data across multiple platforms, such as online banking, physical visits to the bank, ATMs, and customer complaints (D. Barton \& D. Court, 2012). BDA may also vary in terms of accuracy of information as this process requires data from multiple sources to be organized and processed. Information from a variety of sources is often termed "dirty" due to differences in definitions, architectures, and situations. For example, Oakland A's (Athletics), New England Patriots, the Boston Red Sox, and Italy's A.C. Milan use a variety of data (e.g., physiological, orthopedic, and psychological) from multiple sources to provide accurate information for player selection and deployment (Thomas H Davenport, 2006).

The IQUL perception also depends on improved information filtering and better visualization of results through presentation in an appealing and well-formatted manner. BDA should "... transform numbers into information and insights that can be readily put to use versus having to rely on further interpretation or leaving them to languish about uncertainty about how to act"(Lavalle et al., 2011,p.23). Organizations with advanced BDA capabilities use maps, colourful dashboard displays, and advanced visualization tools to provide information in a better format to facilitate adoption and productivity (B. H. Wixom, Yen, \& Relich, 2013). Similarly, BDA may vary due to the currency of information. For example, BDA may yield low-quality information by not reflecting a bank client's most recent transaction. BDA should enable currency of information by embracing the continuous flow of information in the big 
data environment rather than having it sit idly in a data warehouse. Examples of how realtime information can assist are in identifying fraud or detecting changes in customer sentiments.

\section{Information Quality: the Antecedent for Generating Business Value and Managers' Satisfaction in a Big Data Environment}

Organizations with BDA capabilities aim to establish a robust foundation of quality information for decision making and business problem solving (B. H. Wixom et al., 2013). BDA with high information quality facilitate intra-organization operational coordination thus enhancing the effectiveness of functional managers and generating different types of business value, as reflected in Table 2. The research model of this study is based on the appraisalemotional response-coping framework (Bagozzi, 1992; Lazarus, 1991) which suggests that more cognitively-oriented information quality and value appraisal lead to emotive satisfaction, which, in turn, drives firm performance. This study argues that the assessment of analytics-driven information and relevant business value (appraisal) results in an affective or emotional response (i.e., satisfaction), which again leads toward a coping behavior (firm performance). This situation is identified by Bagozzi (1992) as "outcome desire fulfilment" in which a manager in a big data environment assesses information quality and business value to increase satisfaction, which, in turn, influences perceived firm performance.

This study focuses on IQUL dynamics because "quality information" is the primary purpose of any application of BDA; however, few studies have conceptualized BDA in this context. A recent review of IS success studies states that "[i]nformation is the core reason for IS, and Information Quality is particularly important to classes of IS related to business intelligence, data-driven decision making, among others. More research is needed in order to better 
understand how to positively influence Information Quality"(Stacie Petter et al., 2013,p.43). Therefore, the proposed model addresses this gap by modeling the effects of IQUL on BVAL, USAT, and FPER in the BDA context.

\section{Information Quality and Business Value}

Business value is at the heart of what managers pursue from a BDA perspective. The extant literature reports that the business value of analytics will be directly influenced by information quality in a big data environment (B. H. Wixom et al., 2013). The importance of the relationship between IQUL and BVAL was evidenced by Lavalle et al. (2011)'s study ranging over 30 industries across 100 countries. This relationship is also highlighted because, "[t]he goal of big data programs should be to provide enough value to justify their continuation while exploring new capabilities and insights"(Sunil Mithas, Lee, Earley, Murugesan, \& Djavanshir, 2013,p.18). Drawing on Gregor et al.(2006), this study defines business value as having several dimensions, namely, transactional, strategic, and transformational, all of which benefit from BDA. 'Transactional value' refers to the benefits added to firms as a result of IT use through its support of operation management, thus improving efficiency and cutting costs (Mirani \& Lederer, 1998). As shown by Davenport (2006), an alignment between analytics-driven information quality and operational effectiveness results in identifying profitable customers for Harrah's, Capital One, and Barclays, and in maximizing yield for Progressive and Marriott. In a similar spirit, Wixom et al. (2013) indicate that GUESS? INC., the fashion retailer, has been able to use less paper, save time, reduce the number of meetings, and increase cycle time and convenience by embracing BDA.

'Strategic value' takes place when firms change either their strategy (the ways in which they operate) or their products through the use of BDA, with a view to gaining competitive advantages together with offering better products and services to customers than their 
competitors. As reported by Manyika et al. (2011), Amazon.com has been hugely successful in generating strategic business value by implementing BDA for direct marketing using recommendations, such as "you might also want" prompts. These authors also report that Neiman Marcus establishes competitive advantages in customer segmentation and targeting by analyzing their customer profile and real-time changes in customer behavior. Similar strategies have been applied by Harrah's, Progressive Insurance, and Capital One to personalize product offers and increase customer loyalty in a systematic and effective manner. The extant literature focuses on the strategic benefits of BDA, because "[o]ne important benefit is that users develop a deeper understanding of the business ... this understanding led to better purchasing and distribution decisions, and, ultimately, more sales of higher profitability items"(B. H. Wixom et al., 2013,p.118).

Finally, 'transformational value' refers to the benefits which flow into organizations in many forms, such as offering firms a simplification of their business process by restructuring internal organizational processes and activities or performing tasks in an innovative way (Lewis, Åhlström, Yalabik, \& Mårtensson, 2012); (Smith, Ng, \& Maull, 2012); (Maguire et al., 2012); (Caniato, Longoni, \& Moretto, 2012). BDA-driven information quality ensures 'transformational value' by establishing a management culture based on factual and real-time decisions, a single version of the truth, more collaboration, and the discovery of business patterns (B. H. Wixom et al., 2013). Although analytics-driven information quality plays a critical role in generating business value, there is a paucity of empirical studies which confirm this relationship in a big data environment (Goes, 2014; Lavalle et al., 2011; B. H. Wixom et al., 2013). Therefore, the study hypothesizes that:

\section{H1: Perceived IQUL has a significant positive impact on perceived BVAL in BDA.}

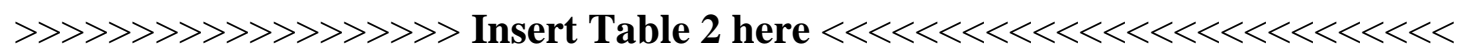




\section{Information Quality, Business Value, and Satisfaction}

The extant literature in marketing (Brady \& Robertson, 2001; Cronin \& Taylor, 1992) and IS (Delone, 2003; Mirani \& Lederer, 1998; Nelson et al., 2005; Barbara H Wixom \& Todd, 2005) identifies information quality as a cognitive construct and as an attitudinal construct. As an 'affective response', scholars identify satisfaction from different viewpoints, such as: a summary attribute phenomenon (Oliver, 1993); an overall evaluation (Claes Fornell, 1992); or a fulfillment response (Oliver, 1993). In a recent study, Golder et al. (2012) state that “[p]ositive quality disconfirmation increases satisfaction; negative quality disconfirmation decreases satisfaction". In this regard, Pitt et al. (1995,p.174) mention that "[t]he principal reason IS departments measure user satisfaction is to improve the quality of service they provide ... Irrespective of whether a user interacts with one or multiple information systems, the quality of service can influence use and user satisfaction". In a meta-analysis on IS user satisfaction, Zviran and Erlich (2003) identify satisfaction as an important outcome construct to evaluate the performance of a system due to its critical effects on decision making and productivity benefits. In a big data environment, scholars (Thomas H Davenport, 2006; A. McAfee \& E. Brynjolfsson, 2012) identify that user satisfaction has a significant impact on BDA use; that is, a higher level of satisfaction creates greater user dependence on BDA. An evaluation of managers' (or users') satisfaction can help to track areas for improvement in order to strengthen BDA systems. In addition to information quality, business value is an important antecedent of satisfaction. According to Fornell et al. (1996) "[t]he first determinant of overall customer satisfaction is perceived quality. The second determinant of overall customer satisfaction is perceived value". Although satisfaction has been used in myriad IS contexts, to date there has been no empirical research on users' satisfaction in BDA. Thus, we postulate that:

\section{H2: Perceived IQUL has a significant positive impact on perceived USAT in BDA.}




\section{H3: Perceived BVAL has a significant positive impact on perceived USAT in BDA.}

\section{Satisfaction and Firm Performance}

In BDA, information quality is widely acknowledged to play a vital role in increasing business and firm performance (B. H. Wixom et al., 2013). The extant literature provides evidence of a relationship between satisfaction and firm performance in, for instance: return on investment (Anderson, Fornell, \& Lehmann, 1994; Anderson, Fornell, \& Rust, 1997; Zeithaml, 2000); operating margin (Bolton, 1998; Rust, Zahorik, \& Keiningham, 1994, 1995); and profitability (C. Fornell, Mithas, \& Morgeson, 2009; C. Fornell, Mithas, Morgeson, \& Krishnan, 2006; Grover \& Ramanlal, 1999; Sunil Mithas et al., 2013; S. Mithas, Tafti, Bardhan, \& Goh, 2012). In the context of healthcare, (Srinivasan \& Arunasalam, 2013) show that the application of BDA in the form of predictive analytics and text mining can benefit firms by reducing cost (i.e., reduced amount of waste and fraud) and improving the quality of care (i.e., safety and efficacy of treatment). Wixom et al. (2013) show that BDA can improve firm performance by improving productivity both in tangible (i.e., less paper reporting) and intangible (company reputation) benefits. Thus, a firm that creates superior user satisfaction should be able to maximize firm performance by facilitating pervasive use and speed via insights from BDA. Following this reasoning, we put forward the following hypothesis:

\section{H4: Perceived USAT has a significant positive impact on perceived FPER in BDA.}

\section{Business Value and Firm Performance}

The extant literature on BDA identifies the relationship between business value and firm performance as one of the key issues for potential investigation (Agarwal \& Dhar, 2014; Sunil Mithas et al., 2013; Sharma et al., 2014; B. H. Wixom et al., 2013). The early research on IT business value focused on impact on organizational performance which includes cost reduction, increased profitability, higher productivity, and competitive advantages (Devaraj \& 
Kohli, 2000; Hitt \& Brynjolfsson, 1996; Kauffman \& Kriebel, 1988; Mukhopadhyay, Kekre, \& Kalathur, 1995; Xia \& Zhang, 2010). This study adopts the "proxy view of IT" in defining the business value of BDA which indicates the individual perceptions of its usefulness or value through firm performance in financial units (Melville, Kraemer, \& Gurbaxani, 2004; Orlikowski \& Iacono, 2001).

\section{H5: Perceived BVAL has a significant positive impact on perceived FPER in BDA.}

\section{MEASUREMENT DEVELOPMENT}

In this study, the development of the US survey measurement items followed an approach similar to the one used by Wixom and Todd (2005) and proposed by Moore and Benbasat (1991). More precisely, all constructs as well as their items were drawn from prior literature and were then adapted to fit the business analytics context (Table 3). Afterward, eight experienced IS academics went through the survey to ensure the content validity. Next, a pilot testing of the questionnaire was conducted with a total of 52 respondents recruited from various business analytics groups on LinkedIn following the same process as was used for the subsequent main survey (Pavlou \& Fygenson, 2006). A 7-point Likert scale was used for all our items.

Once the US version of the survey in English was validated, a process similar to the one used by Venkatesh et al. (2012) was followed to translate the English version of the survey into French. This consisted of a professional translator translating the survey into French and then back into English to ensure the reliability of the translation. A bilingual member of the research team went through the two versions of the survey to validate the translation. A pretest of the final French questionnaire with nine respondents was then realized to confirm the construct validity. Subsequently, the combined 61 respondents were used to assess the robustness of our proposed model. 


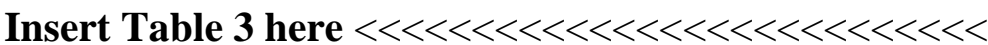

\section{SURVEY ADMINISTRATION}

The main survey for this study was administrated by a leading market research firm in the US that does sampling and data collection. The data collection for the two samples was conducted from April 4, 2014 to April 17, 2014. For the French sample, an invitation to participate in the study was sent on April 04, 2014 to a random sample of 500 members of the business analysts, business analytics, and IT professionals' French panel. In all, 337 panel members agreed to participate in the study. A reminder was sent to participants on April 10, 2014, and the survey was closed on April 17, 2014. After a careful analysis of all responses, 150 valid questionnaires were considered to have been correctly filled out and appropriate for further analysis. Thus, for the French sample, we had a response rate of $44.51 \%$.

A similar process was used to collect data in the US. More precisely, an invitation to participate in the study was sent on April 07, 2014 to a random sample of 826 members of the business analysts, business analytics, and IT professionals' US panel. A total of 668 panel members agreed to participate in the study. A reminder was sent to participants on April 12, 2014, and the web-based questionnaire was closed on April 17, 2014. After a careful analysis of all responses, 152 valid questionnaires were considered to have been correctly filled out and appropriate for further analysis. Therefore, for this study, we had a response rate of $22.75 \%$, giving a final sample of 302 useful responses.

\section{DATA ANALYSIS}

We applied partial least squares (PLS) path modeling (Tenenhaus, Vinzi, Chatelin, \& Lauro, 2005) to estimate the theoretical model. According to Becker et al. (2013), unobserved heterogeneity may arise in an PLS based modeling. This is particularly true in BDA, where it is unrealistic that a unique model may fit all the units. 
We used the REBUS-PLS algorithm (Esposito Vinzi et al., 2008) to investigate the presence of unobserved heterogeneity in our sample. Recently Becker et al. (2013) presented a modification of the original REBUS-PLS algorithm, that is, the PLS-POS algorithm. Both of these methods allow unobserved heterogeneity to be accounted for in the whole model (i.e., the measurement as well as the structural part). In comparison to the REBUS-PLS algorithm, the PLS-POS algorithm applies to both formative and reflective indicators. However, the PLS-POS algorithm requires the number of unobserved groups to be defined prior. When no prior information can be used to predefine the number of groups to detect, the analysis has to be run several times with a different number of groups. The solution that best fit the data is retained. However, in REBUS-PLS, the algorithm automatically detects the number of unobserved groups. This is a key advance when there is no information about the existence (and the number) of groups. Since our model only involves a reflective measurement model and no prior information was available on the number of groups to be used, we decided to apply the REBUS-PLS algorithm. The REBUS-PLS algorithm provides, at the same time, group membership for each respondent and group-specific model parameters. Moreover, posthoc analyses were run to characterize the REBUS-PLS-detected groups according to manager demographic characteristics and years of experience as well as firm size.

\section{RESULTS AND DISCUSSION}

The REBUS-PLS algorithm is available in XLSTAT-PLS, version 2013.6.04. According to (W. W. Chin, 2010), all item loading values higher than 0.70 are considered to be adequate. Moreover, composite reliability (CR) values higher than 0.70 are considered to be acceptable. For average variance extracted (AVE), a value that is higher than 0.50 is considered to be an acceptable measure justifying the use of a construct (Sun \& Zhang, 2008). 


\section{Execution of the REBUS-PLS AIgorithm and Measurement Validation}

The REBUS-PLS algorithm automatically detected three groups of units of similar size (G1, G2 and G3). More precisely, 98 respondents were included in the first group, G1 (i.e., $34 \%$ of the sample), 108 comprised the second group, G2 (i.e., $36 \%$ of the sample), and the third group, G3, was composed of the remaining 96 respondents (i.e., $32 \%$ of the sample).

In addition, composite reliability was verified for all the constructs both in the global model and in the local models (see Table 4) (W. W. Chin, 2010). All items, with the exception of the one associated to BVTR1 in the local model estimated for G2, strongly loaded on the corresponding construct. Since standardized loading associated to BVTR1 was higher than 0.8 in the other two groups and in the global model, we decided to retain it in the analysis. The AVE indexes were higher than 0.60 for all the constructs in the global and local models and they always exceeded the threshold of 0.5 defined by Fornell and Larcker (1981). Discriminant validity, verified at the global model level as the square root of each AVE value in Table 4, exceeded the inter-construct correlations in all the models (see Table 5 to Table 8) (Barclay, Higgins, \& Thompson, 1995; W. W. Chin, 1998; C. Fornell \& Larcker, 1981). However, the correlation between IQUL and BVAL exceeded the square root of the AVE associated to BVAL in the local models estimated for both groups 1 and 2 (see Table 6 and Table 7). Multicollinearity among the constructs was tested. Variance inflation factors (VIF) indexes are reported along with the structural model results in Table 9. All the VIF values are smaller than 10 indicating that no serious multicollinearity affected the structural models at either global or local levels (Hair, Tatham, Anderson, \& Black, 2006; Neter, Wasserman, \& Kutner, 1990; S. Petter, Straub, \& Rai, 2007). The only VIF value exceeding the threshold of 5 (Kline, 1998) was the one measuring the multicollinearity between IQUL and BVAL in predicting USAT in G1 (Table 9). This was consistent with the discriminant validity results, 
indicating that IQUL and BVAL were more highly correlated for respondents in G1 than for all the other respondents.

The estimated local models differed based on the relationships in the structural model and some of the mean values of the second-order constructs. Two-tailed $t$-tests with a Bonferroni correction were run to compare item and construct means across groups. In Table 10, we report the mean values of all items at the aggregate and group levels. The results of the twotailed Bonferroni tests for pairwise comparisons are presented in Table 11. According to the results reported in Table 10 and Table 11, respondents in G2 showed higher item mean values than respondents in G1 and G3. This was particularly true for all items related to Strategic and Transformational aspects of BVAL and for those associated to FPER.

Respondents in G3 had lower values for all items with the exception of the one related to the Currency, Format and Accuracy aspects of IQUL. In particular, they had significant lower values for all the items associated to FPER. The main construct means are reported in Table 12. The results of pairwise comparisons among the construct means are reported in Table 13. The mean values of all the constructs except for IQUL are significantly different across groups. In particular, G2 was characterized by significant higher mean values for FPER and BVAL, while respondents in G1 were characterized by a significant higher mean value for USAT. In accordance with the item mean values, G3 was characterized by the lowest mean values for all constructs. This was particularly true for FPER: respondents in G3 showed a mean value that was more than 1 point (on a 7-point scale) smaller than the other two groups.

\section{The Structural Model}

The results of the structural model testing are presented in Figure 2, and Table 9 and Table 14. In Figure 2, we present the estimated structural path models at global model level as well 
as at group level. The arrow thickness on the path depends on the significance associated at each path coefficient. As for the structural models, the three groups show different patterns of relationships among the second-order latent constructs: USAT and FPER (see Figure 2 and Table 14 and Table 9). In general, G1 shows higher $\mathrm{R}^{2}$ values than the others, but it is also the group for which the correlations among the latent constructs are higher (see Table 5 to Table 8). Each of the inner relationships is discussed below.

\section{Impact on Business Value}

Table 9 shows that IQUL has a significant positive effect on BVAL for the global model and all three detected local models: G1, G2, and G3, thus support H1 for global model, G1, G2 and G3. In addition, the impact of IQUL on BVAL is significantly higher for respondents in G1 compared to both the global and the other local models, G2 and G3 (see Table 14).

\section{Impact on Satisfaction}

In the proposed model, we assumed that USAT would be explained by IQUL and BVAL. At the global model level, both IQUL and BVAL have the same significant positive effect on USAT (Table 9), thus validating $\mathbf{H 2}$ and $\mathbf{H 3}$ at the global level (Table 16). Similarly, for respondents in G2, IQUL and BVAL still show significant positive effects on USAT (Table 9), thus validating $\mathbf{H 2}$ and $\mathbf{H 3}$ for $\mathbf{G 2}$ (Table 16). However, for respondents in G2, the main driver of USAT is BVAL, which contributes about $82 \%$ of explained variability, while IQUL only accounts for $8 \%$ of explained variability (Table 9). Differences occur when comparing models estimated for respondents in G1 and G3 (Table 14). For respondents in G3, BVAL is the only significant driver of USAT and it alone explains $55 \%$ of the variability of USAT $\left(\mathrm{R}^{2}\right.$ = 0.55) (Table 9), thus validating only $\mathbf{H 3}$ for G3 (Table 16).

On the other hand, for respondents in G1, the only significant driver of USAT is IQUL: that alone accounts for $86 \%$ of the variability of USAT $\left(\mathrm{R}^{2}=0.86\right)($ Table 9$)$, thus validating $\mathbf{H 2}$ for G3 (Table 16). The non-significance of the coefficient linking BVAL to USAT in G1 may 
be due to the high correlation between the two independent variables: therefore, caution must be applied in interpreting this result. However, the VIF value associated to this structural relationship is smaller than 10 (Table 9), indicating that no serious multicollinearity affects the structural model for G1 (S. Petter et al., 2007).

\section{Impact on Firm Performance}

In the proposed model, we assumed that FPER would be directly dependent on BVAL and USAT. As shown in Table 9, the two exogenous variables have significant positive effects on FPER for all groups, thus validating $\mathrm{H4}$ and $\mathrm{H5}$ for the three groups, G1, G2 and G3, as well as for the global model (Table 16). However, at global model level and for respondents in G1, BVAL is the most important driver of FPER explaining $85 \%$ or more of the explained variability (Table 9). This is not true for respondents in G2 and G3, for whom BVAL and USAT have the same impact on FPER. In particular, respondents in G3 seem to be more satisfaction-driven than those in G2 (Table 14).

The groups detected with the REBUS-PLS method can be characterized according to their demographic characteristics. For a given demographic variable, we computed the percentage of respondents showing a specific category (relative frequency per category [\%] in Table 15). We tested the difference between the relative frequencies among the groups by applying Chisquare tests for proportion. Manager proportions among the groups were not significantly different with respect to the country of the respondents and the size of the firm where they were employed.

However, G3 is characterized by a more significantly (at a level of significance of 0.05 ) high percentage of female respondents than all other groups. Moreover, no respondent in this group had a primary qualification. There is a significantly high proportion of young respondents (younger than 33 years old) in G1 and, as a consequence, this group is characterized by managers with less years of experience compared to the other two groups. 
The G2 mimics sample composition with regard to all the demographic characteristics. However, there were no managers lacking formal education in G2.

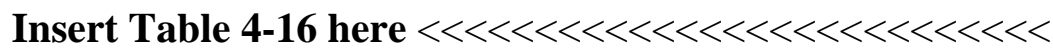

\section{DISCUSSION}

This study extended a theory of manager-side BDA strategy by highlighting the impact of information quality on firm performance. Specifically, the study investigated the dynamics of information quality-a critical aspect of BDA- on firm performance by identifying the indirect impacts of business value and user satisfaction. The information quality dynamics are assessed for analytics organizations across the US and France by collecting data from 302 business analysts and empirically testing the conceptual model. The findings of the study clearly indicate that information quality in BDA has a significant direct impact on business value and user satisfaction and indirect impact on firm performance. The findings also indicate that the associations between information quality and firm performance are stronger in BDA with the increased business value and user satisfaction. Our investigation of manager-side information quality dynamics makes key theoretical, methodological and practical contributions to the emerging BDA literature and business strategy.

\section{THEORETICAL CONTRIBUTIONS}

By exploring information quality dynamics in manager-side operations, the study advances prior research in BDA that has primarily focused on anecdotal evidences to improve firm performance. This study contributes by arguing for information quality and business value driven decisions, which is a key perspective in the BDA research (Agarwal \& Dhar, 2014; Goes, 2014; B. H. Wixom et al., 2013). Manager-side information quality dynamics have received increased attention in IS and BDA research in recent years (Thomas H Davenport, Paul Barth, \& Randy Bean, 2012; Stacie Petter et al., 2013; Schroeck et al., 2012), however, 
there is a paucity of research in this domain leveraging such dynamics in enhancing firm performance. Drawing on IS and BDA literature, the study develops a model on information quality dynamics as a direct response to the research call of manager-side BDA strategies (Agarwal \& Dhar, 2014; Goes, 2014; Sharma et al., 2014; B. H. Wixom et al., 2013).

By presenting the theory of information quality driven BDA strategy, this study gives an impetus to research on data quality in big data environment (D Barton \& D Court, 2012; Andrew McAfee \& Erik Brynjolfsson, 2012). Although data quality are widely known to be important in big data environment, our study extends prior research by showing ways to leverage information quality and business value to enhance firm performance. Further, the encapsulation of quality-value-satisfaction- performance might start a new debate and facilitate new research on the alignment between analytics and business value (Liebowitz, 2013). For example, future research could identify BDA strategies to improve decisions in product and service quality, satisfaction and customer loyalty (T. H. Davenport, 2006), pricing and customer choice preferences (Thomas H Davenport \& Harris, 2007), market share analysis (Manyika et al., 2011) and new product adoption rate (Chandrasekaran, Levin, Patel, \& Roberts, 2013).

The study also contributes by conceptualizing a manager-side BDA strategy that is focused on information quality. Although information quality, an important aspect in BDA, is evidenced to influence business value and manager satisfaction. Our theory and associated analyses are at the level of overall information quality, which did not take into account individual dimensions of information quality in linking with outcome constructs. Indeed, there might be different impact of four appraisal dimensions of information quality on two emotional responses, namely business value and satisfaction. Future studies might be conducted at a dimension level analysis to extend the literature on information quality in BDA (Stacie Petter et al., 2013; Setia et al., 2013). A dimensional analysis of information quality on business 
value and user satisfaction will help analysts assess specific features of information and their role in better decision making in BDA. Future research may also evaluate the quality dynamics for aligning the information systems with BDA and the best practices of IT management (Andrew McAfee \& Erik Brynjolfsson, 2012).

Overall, the findings of our study are likely to create new avenues of research to assess appraisal-emotional response-coping of a firm's big data decisions. The findings show that although information quality dimensions have strong direct impact on business value and customer satisfaction, they have strong indirect impact on firm performance. This finding evidences that the quality of information and corresponding business value (appraisal) results in an affective or emotional response (i.e., satisfaction), which again leads toward a coping behaviour (firm performance). This argument indicates that behavioural dynamics play an important role in firm's BDA decision. This conceptualization opens up a new stream of inquiry that reveals the behavioural side of big data strategy (Agarwal \& Dhar, 2014; Agarwal \& Weill, 2012). Future research might delve into examining customer's perceptions of BDA and firm's ability to meet such expectations on customer value, satisfaction and continuance intentions. Future studies might also explore analytics capability dimensions of a firm, which will definitely facilitate the development of literature in BDA strategy. Given the increased importance of business analytics in facilitating firm competitive advantage, future studies may build upon our proposed determinants to explore the potential of business analytics at the process, inter-organizational, and societal levels (Chang, Kauffman, \& Kwon, 2014; Saeed, Malhotra, \& Grover, 2005).

\section{METHODOLOGICAL CONTRIBUTIONS}

This study integrates constructs from Barbara H Wixom and Todd (2005), Gregor et al. (2006), Spreng, MacKenzie, and Olshavsky (1996), and Tippins and Sohi (2003) to study the potential of BDA in enabling firm performance. However, unlike these earlier studies that 
investigated the relationship between the independent and dependent variables at the global level, the current study argues that the adoption behavior varies among business analysts of any given IT artifact. Therefore, only assessing the importance of the relationship between independent and dependent variables at the global level does not capture these differences or the unobserved heterogeneity that exists in social data (Jedidi et al., 1997). Consequently, the study uses the REBUS-PLS, which is a response-based method, to capture this unobserved heterogeneity (Esposito Vinzi et al., 2008). In addition, this study is a response to the call by Becker et al. (2013) for more studies that investigate unobserved heterogeneity. The authors found very few articles published in leading IS journals over the last 20 years that had used a structural model and that had "examined unobserved heterogeneity". In fact, these studies assumed that empirical data are homogeneous and represent a single population, thus leading to possible bias during the assessment of structural model parameters. Furthermore, the application of the REBUS-PLS algorithm allows the identification of three groups of business analytics users (G1, G2, and G3), which are all characterized by different user's behaviors (e.g., different in values for structural model parameters). These results may facilitate the design of analytics systems that fit each user's behaviours across each identified group, thus facilitating the adoption and use of the analytics, as well as the extended use of the systems.

\section{IMPLICATIONS FOR PRACTICE}

With the advent of analytics driven economy, this study has many practical implications for enhancing organisational performance irrespective of size. Our study suggests that firms need to embrace information quality dynamics to leverage their analytics capability. Because of the importance of IQUL-BVAL-USAT-FPER focus of the BDA organization, such orientation may be a sustained source of long term competitive advantage. Since information quality leads to valuable insights, managers in big data environment need to emphasize on such 
priority in order to improve decision making across the organization (Thomas H Davenport et al., 2012).

This study has huge practical implications for various industries using BDA, such as, retail, manufacturing, healthcare and public sector administration. There is a growing focus on information quality dynamics in BDA environment across these industries (Manyika et al., 2011). According to an estimate by BSA Software Alliance (Columbus, 2014) in the US, $10 \%$ or more of the growth were related to analytics driven information for $56 \%$ of firms in 2014. $81 \%$ decision makers see analytics being a major contributor to $10 \%$ or more of their companies' growth by 2019. Furthermore, the findings of the study also clearly indicate that analytics driven decision makers will better serve customer needs (79\%), increase sales and revenue $(76 \%)$, create new products and services (70\%) and expand into new markets $(72 \%)$ with the help of quality information and robust insights. Overall, $69 \%$ of the US decision makers and $65 \%$ of the European decision makers have emphasized analytics driven decision making on quality information (Columbus, 2014), as data have become a torrent flowing into every area of global economy (Cukier, 2010). A recent study shows that BDA can reduce the costs of administrative decision making in EU by $\$ 446$ billion and improve global R\&D productivity by $\$ 100$ billion (Manyika et al., 2011). Companies including Tesco, Amazon, Wal-Mart, Harrah's, Progressive Insurance, Capital One and Smart (Philippines) have already evidenced their early successes by embracing analytics driven information as a competitive weapon. Therefore, the findings of the study recommend a focus on information quality dynamics in big data environment to enhance business value, satisfaction and firm performance. The findings of the study will also help identify distinctive groups of BDA users, which may contribute to facilitating the design of features and interfaces that match user group's desires, thus fostering user acceptance and use of analytics systems. For example, Harrah's Entertainment leverages analytics and quality information to select 
customers with the greatest profit potential and customize price and promotions for the targeted segments. In addition to marketing decisions, they also use analytics for people decisions by allocating the right staff to the right touch point for ensuring more satisfaction to its employees as well as guests (Thomas H Davenport, Harris, \& Shapiro, 2010). The findings of the study identify distinctive user groups, which may allow project stakeholders in charge of designing training programs and interventions to provide more targeted and personalized training to each group. In a similar spirit, Davenport et al. (2010,p.58) state that, "Future organizational performance is inextricably linked to the capabilities and motivations of a company's people. Organizations that have used data to gain human-capital insights already have a hard-to replicate competitive advantage".

\section{LIMITATIONS}

The study has several limitations. Firstly, the vast majority of items used for our constructs were measured using a 7-point Likert scale which was anchored ranging from "strongly disagree"(1) to "strongly agree"(7), and thus may introduce the so-called "acquiescence bias" which is related to the "respondents' tendency to respond to items positively without much regard for its true content" (W. W. Chin, Johnson, \& Schwarz, 2008). Therefore, future studies may consider using the 9-point scale of fast form items with the two-anchor points ranging from -4 to +4 as suggested by Chin et al. (2008). Secondly, the BDA-enabled improved firm performance cannot be fully assessed by a limited set of determinants. Therefore, further research might attempt to integrate more determinants including, for example, information quality with system quality (Barbara H Wixom \& Todd, 2005), or service quality with information quality (Xu et al., 2013). Thirdly, this study measures the direct impact of a set of determinants of BDA directly on firm performance. Future studies should look at the first-order impact of BDA, which is the impact at the process level (Barua, 
Kriebel, \& Mukhopadhyay, 1995; Mooney, Gurbaxani, \& Kraemer, 1996). Specifically, to offer deeper view of the impacts of BDA, future research may focus on behavioural dynamics in a customer-side BDA strategy. Further, findings on the moderating role of business analytics capability are likely to open new avenues of research.

\section{CONCLUSION}

BDA have emerged as the new frontier of innovation and competition in the wide spectrum of the business landscape due to the challenges and opportunities created by the information revolution. BDA increasingly provide value to firms using the dynamics of information quality that transform data into insights for robust decision making and solving business problems. This is a holistic process which deals with data, sources, skills, and systems in order to create a competitive advantage. Leading e-commerce firms like Google, Amazon, and Facebook have already embraced BDA driven decisions and experienced enormous growth. This study presents a useful starting point for understanding the IQUL dynamics in a big data environment by modelling their impact on BVAL, USAT, and FPER. The study reflects that once BDA-driven IQUL is well understood and challenges are properly addressed, the BDA application will maximize business value, which indeed facilitates pervasive usage and speedy delivery of insights for decision making across organizations.

\section{REFERENCES}

Agarwal, R., \& Dhar, V. (2014). Editorial-Big Data, Data Science, and Analytics: The Opportunity and Challenge for IS Research. Information Systems Research, 25(3), 443-448.

Agarwal, R., \& Weill, P. (2012). The Benefits of Combining Data With Empathy. MIT Sloan Management Review, 54(1), 35.

Anderson, E. W., Fornell, C., \& Lehmann, D. R. (1994). Customer satisfaction, market share, and profitability: findings from Sweden. the Journal of Marketing, 53-66.

Anderson, E. W., Fornell, C., \& Rust, R. T. (1997). Customer satisfaction, productivity, and profitability: differences between goods and services. Marketing Science, 16(2), 129-145.

Bagozzi, R. P. (1992). The Self-Regulation of Attitudes, Intentions, and Behavior. Social Psychology Quarterly, 55(2), 178-204. doi:10.2307/2786945

Barclay, D., Higgins, C., \& Thompson, R. (1995). The partial least squares (PLS) approach to causal modeling: Personal computer adoption and use as an illustration. Technology studies, 2(2), 285-309. 
Barton, D., \& Court, D. (2012). Making advanced analytics work for you. Harvard business review, 90(10), 79-83.

Barton, D., \& Court, D. (2012). Making advanced analytics work for you. Harvard business review, 90(10), 78.

Barua, A., Kriebel, C. H., \& Mukhopadhyay, T. (1995). Information Technology and Business Value: An Analytic and Empirical Investigation. Information Systems Research, 6(1), 3-23.

Becker, J.-M., Rai, A., Ringle, C. M., \& Völckner, F. (2013). Discovering unobserved heterogeneity in structural equation models to avert validity threats. MIS Quarterly, 37(3), 665-694.

Bolton, R. N. (1998). A dynamic model of the duration of the customer's relationship with a continuous service provider: the role of satisfaction. Marketing Science, 17(1), 45-65.

Boyd, D., \& Crawford, K. (2012). Critical questions for big data: Provocations for a cultural, technological, and scholarly phenomenon. Information Communication and Society, 15(5), 662-679.

Brady, M. K., \& Robertson, C. J. (2001). Searching for a Consensus on the Antecedent Role of Service Quality and Satisfaction: An Exploratory Cross-National Study. Journal of Business Research, 51(1), 53-60.

Caniato, F., Longoni, A., \& Moretto, A. (2012). Effective eProcurement implementation process. Production Planning \& Control, 23(12), 935-949.

Chandrasekaran, S., Levin, R., Patel, H., \& Roberts, R. (2013). Winning with IT in consumer packaged goods: Seven trends transforming the role of the ClO. Retrieved from

Chang, R. M., Kauffman, R. J., \& Kwon, Y. (2014). Understanding the paradigm shift to computational social science in the presence of big data. Decision Support Systems, 63(0), 67-80. doi:http://dx.doi.org/10.1016/i.dss.2013.08.008

Chin, W. W. (1998). The partial least squares approach to structural equation modeling. Modern methods for business research, 295(2), 295-336.

Chin, W. W. (2010). How to write up and report PLS analyses. In Handbook of partial least squares (pp. 655-690). Berlin: Springer Berlin Heidelberg.

Chin, W. W., \& Dibbern, J. (2010). An introduction to a permutation based procedure for multi-group PLS analysis: Results of tests of differences on simulated data and a cross cultural analysis of the sourcing of information system services between Germany and the USA. In Handbook of partial least squares (pp. 171-193): Springer.

Chin, W. W., Johnson, N., \& Schwarz, A. (2008). A Fast Form Approach to Measuring Technology Acceptance and Other Constructs. MIS Quarterly, 32(4), 687-703. doi:10.2307/25148867

Columbus, L. (2014, 12/10/2014). Making Analytics Accountable: 56\% Of Executives Expect Analytics to Contribute To $10 \%$ Or More Growth in 2014. Forbes. Retrieved from http://www.forbes.com/sites/louiscolumbus/2014/12/10/making-analytics-accountable-56of-executives-expect-analytics-to-contribute-to-10-or-more-growth-in-2014/

Cronin, J. J. J., \& Taylor, S. A. (1992). Measuring Service Quality: A Reexamination and Extension. Journal of Marketing, 56(3), 55-68. doi:10.2307/1252296

Crowston, K. (1997). A coordination theory approach to organizational process design. Organization Science, 8(2), 157-175.

Cukier, K. (2010). Data, data everywhere: A special report on managing information: Economist Newspaper.

Davenport, T. H. (2006). Competing on analytics. Harvard business review, 84(1), 98-107.

Davenport, T. H. (2006). Competing on analytics. In (pp. 99-107).

Davenport, T. H. (2010). The New World of "Business Analytics. Retrieved from

Davenport, T. H. (2012). The Human Side of Big Data and High-Performance Analytics. Retrieved from

Davenport, T. H., Barth, P., \& Bean, R. (2012). How 'Big Data'is Different. MIT Sloan Management Review, 54(1), 43-46.

Davenport, T. H., Barth, P., \& Bean, R. (2012). How Big Data Is Different. MIT Sloan Management Review, 54(1), 43-46. 
Davenport, T. H., Harris, J., \& Shapiro, J. (2010). Competing on talent analytics. Harvard business review, 88(10), 52-58.

Davenport, T. H., \& Harris, J. G. (2007). Competing on analytics: the new science of winning: Harvard Business School Press.

Davenport, T. H., Harris, J. G., Jones, G. L., \& Lemon, K. N. (2007, May 2007). The Dark Side of Customer Analytics. Harvard business review, 85, 37-48.

Davenport, T. H., \& Patil, D. (2012). Data scientist: the sexiest job of the 21st century. Harvard business review, 90(10), 70-77.

Delone, W. H. (2003). The DeLone and McLean model of information systems success: a ten-year update. Journal of Management Information Systems, 19(4), 9-30.

DeLone, W. H., \& McLean, E. R. (1992). Information systems success: the quest for the dependent variable. Information Systems Research, 3(1), 60-95.

Devaraj, S., \& Kohli, R. (2000). Information technology payoff in the health-care industry: a longitudinal study. Journal of Management Information Systems, 41-67.

Dijcks, J. P. (2012). Oracle: Big Data for the Enterprise. In: Oracle.

Durcikova, A., \& Gray, P. (2009). How knowledge validation processes affect knowledge contribution. Journal of Management Information Systems, 25(4), 81-108.

Economist. (2010, February 25). Data, Data Everywhere. Economist.

Esposito Vinzi, V., Trinchera, L., Squillacciotti, S., \& Tenenhaus, M. (2008). REBUS-PLS: A responsebased procedure for detecting unit segments in PLS path modelling. Applied Stochastic Models in Business and Industry, 24(5), 439-458. doi:10.1002/asmb.728

Fisher, D., DeLine, R., Czerwinski, M., \& Drucker, S. (2012). Interactions with Big Data Analytics. Interactions, 19(3), 50.

Fornell, C. (1992). A national customer satisfaction barometer: the Swedish experience. the Journal of Marketing, 6-21.

Fornell, C., Johnson, M. D., Anderson, E. W., Cha, J., \& Bryant, B. E. (1996). The American Customer Satisfaction Index: Nature, Purpose, and Findings. Journal of Marketing, 60(4), 7-18. doi: $10.2307 / 1251898$

Fornell, C., \& Larcker, D. F. (1981). Structural equation models with unobservable variables and measurement error: Algebra and statistics , 382-388. Journal of Marketing Research, 18(3), 382-388.

Fornell, C., Mithas, S., \& Morgeson, F. V. (2009). The economic and statistical significance of stock returns on customer satisfaction. Marketing Science, 28, 820-825.

Fornell, C., Mithas, S., Morgeson, F. V., \& Krishnan, M. S. (2006). Customer satisfaction and stock prices: high returns, low risk. Journal of marketing, 70, 3-14.

Forrester. (2012). The Big Deal About Big Data For Customer Engagement Business: Leaders Must Lead Big Data Initiatives To Derive Value. Retrieved from http://www.forrester.com/The+Big+Deal+About+Big+Data+For+Customer+Engagement/fullt ext/-/E-RES72241

Gelsinger, P. (2012). Big Bets On Big Data. Forbes. Retrieved from http://www.forbes.com/sites/ciocentral/2012/06/22/big-bets-on-bigdata/?goback=.gde 2013423 member 127364385

Goes, P. B. (2014). Big Data and IS Research. MIS Quarterly, 38(3), iii-viii.

Golder, P. N., Mitra, D., \& Moorman, C. (2012). What is quality? an integrative framework of processes and states. Journal of marketing, 76(4), 1-23.

Gregor, S., Martin, M., Fernandez, W., Stern, S., \& Vitale, M. (2006). The transformational dimension in the realization of business value from information technology. The Journal of Strategic Information Systems, 15(3), 249-270.

Grover, V., \& Ramanlal, P. (1999). Six Myths of Information and Markets: Information Technology Networks, Electronic Commerce, and the Battle for Consumer Surplus. MIS Quarterly, 23(4), 465-495. doi:10.2307/249486 
Hair, J. F., Tatham, R. L., Anderson, R. E., \& Black, W. (2006). Multivariate data analysis. NJ: Pearson Prentice Hall.

Havens, T. C., Bezdek, J. C., Leckie, C., Hall, L. O., \& Palaniswami, M. (2012). Fuzzy c-Means Algorithms for Very Large Data. Fuzzy Systems, IEEE Transactions on, 20(6), 1130-1146. doi:10.1109/tfuzz.2012.2201485

Hitt, L. M., \& Brynjolfsson, E. (1996). Productivity, business profitability, and consumer surplus: three different measures of information technology value. MIS Quarterly, 121-142.

IBM. (2012). What is big data? Retrieved from http://www-01.ibm.com/software/data/bigdata/

IDC. (2013). Big Data in 2020. Retrieved from http://www.emc.com/leadership/digitaluniverse/iview/big-data-2020.htm

Jacobs, A. (2009). The Pathologies of Big Data. Association for Computing Machinery. Communications of the ACM, 52(8), 36.

Jedidi, K., Jagpal, H. S., \& DeSarbo, W. S. (1997). Finite-mixture structural equation models for response-based segmentation and unobserved heterogeneity. Marketing Science, 16(1), 3959.

Johnson, B. D. (2012). The Secret Life of Data. The Futurist, 46(4), 20-23.

Kauffman, R. J., \& Kriebel, C. H. (1988). Modeling and Measuring the Business Value of Information Technology. Stern School of Business, New York University. New York.

Kiron, D., Prentice, P. K., \& Ferguson, R. B. (2012). Innovating with Analytics. MIT Sloan Management Review, 54(1).

Kiron, D., \& Shockley, R. (2011). Creating Business Value with Analytics. MIT Sloan Management Review, 53(1), 57-63.

Kline, R. B. (1998). Principles and practice of structural equation modeling New York: The Guilford Press.

Lavalle, S., Lesser, E., Shockley, R., Hopkins, M. S., \& Kruschwitz, N. (2011). Big Data, Analytics and the Path From Insights to Value. MIT Sloan Management Review, 52(2), 21-32.

Lazarus, R. S. (1991). Emotion and adaptation: Oxford University Press.

Lewis, M., Åhlström, P., Yalabik, B., \& Mårtensson, P. (2012). Implementing advanced service technology in the public sector: an exploratory study of the relevance and limitations of insights from private sector manufacturing technology implementation. Production Planning \& Control, 24(10-11), 916-930. doi:10.1080/09537287.2012.666901

Liebowitz, J. (2013). Big Data and Business Analytics: CRC Press.

Maguire, S., Ojiako, U., Papadopoulos, T., Shafti, F., Koh, L., \& Kanellis, P. (2012). Synchronicity and alignment of productivity: the real value from Service Science? Production Planning \& Control, 23(7), 498-512. doi:10.1080/09537287.2011.640038

Malone, T. W., \& Crowston, K. (1990). What is coordination theory and how can it help design cooperative work systems? Paper presented at the Proceedings of the 1990 ACM conference on Computer-supported cooperative work.

Malone, T. W., \& Crowston, K. (1994). The interdisciplinary study of coordination. ACM Computing Surveys (CSUR), 26(1), 87-119.

Manyika, J., Chui, M., Brown, B., Bughin, J., Dobbs, R., Roxburgh, C., \& Byers, A. H. (2011). Big data: The next frontier for innovation, competition, and productivity. Retrieved from

McAfee, A., \& Brynjolfsson, E. (2012). Big Data: The Management Revolution. Harvard business review, 90(10), 60-68.

McAfee, A., \& Brynjolfsson, E. (2012). Big data: the management revolution. Harvard business review, 1.

Melville, N., Kraemer, K., \& Gurbaxani, V. (2004). INFORMATION TECHNOLOGY AND ORGANIZATIONAL PERFORMANCE: AN INTEGRATIVE MODEL OF IT BUSINESS VALUE. MIS Quarterly, 28(2), 283-322.

Mirani, R., \& Lederer, A. L. (1998). An instrument for assessing the organizational benefits of IS projects. Decision Sciences, 29(4), 803-838. 
Mithas, S., Lee, M. R., Earley, S., Murugesan, S., \& Djavanshir, R. (2013). Leveraging Big Data and Business Analytics. IT Professional, 15(6), 18-20.

Mithas, S., Ramasubbu, N., \& Sambamurthy, V. (2011). How information management capability influences firm performance. MIS Quarterly, 35(1), 237-256.

Mithas, S., Tafti, A., Bardhan, A., \& Goh, J. M. (2012). Information technology and firm profitability: mechanisms and empirical evidence. MIS Quarterly, 36(1), 205-224.

Mooney, J. G., Gurbaxani, V., \& Kraemer, K. (1996). A process oriented framework for assessing the business value of information technology. The Data Base for Advances in Information Systems, 27, 68-81.

Moore, G. C., \& Benbasat, I. (1991). Development of an Instrument to Measure the Perceptions of Adopting an Information Technology Innovation. Information Systems Research, 2(3), 192222. doi:doi:10.1287/isre.2.3.192

Mukhopadhyay, T., Kekre, S., \& Kalathur, S. (1995). Business value of information technology: a study of electronic data interchange. MIS Quarterly, 19(2), 137-156.

Nelson, R. R., Todd, P. A., \& Wixom, B. H. (2005). Antecedents of information and system quality: an empirical examination within the context of data warehousing. Journal of Management Information Systems, 21(4), 199-235.

Neter, J., Wasserman, W., \& Kutner, M. H. (1990). Applied Linear Statistical Models: Regression, Analysis of Variance, and Experimental Design (3rd ed.). New-York: McGraw-Hill, Inc.

Oliver, R. L. (1993). Cognitive, affective, and attribute bases of the satisfaction response. Journal of consumer research, 418-430.

Orlikowski, W. J., \& lacono, C. S. (2001). Research commentary: Desperately seeking the" it" in it research-a call to theorizing the it artifact. Information Systems Research, 12(2), 121-134.

Pavlou, P. A., \& Fygenson, M. (2006). Understanding and Predicting Electronic Commerce Adoption: An Extension of the Theory of Planned Behavior. MIS Quarterly, 30(1), 115-143. doi: $10.2307 / 25148720$

Petter, S., DeLone, W., \& McLean, E. R. (2013). Information systems success: The quest for the independent variables. Journal of Management Information Systems, 29(4), 7-62.

Petter, S., Straub, D., \& Rai, A. (2007). Specifying formative constructs in information systems research. MIS Quarterly, 31(4), 623-656.

Pitt, L. F., Watson, R. T., \& Kavan, C. B. (1995). Service quality: a measure of information systems effectiveness. MIS Quarterly, 173-187.

Rouse, M. (2011). big data (Big Data). Retrieved from http://searchcloudcomputing.techtarget.com/definition/big-data-Big-Data

Rust, R. T., Zahorik, A. J., \& Keiningham, T. L. (1994). Return on quality: Measuring the financial impact of your company's quest for quality: Probus Chicago.

Rust, R. T., Zahorik, A. J., \& Keiningham, T. L. (1995). Return on quality (ROQ): making service quality financially accountable. the Journal of Marketing, 58-70.

Saeed, K. A., Malhotra, M. K., \& Grover, V. (2005). Examining the impact of interorganizational systems on process efficiency and sourcing leverage in buyer-supplier dyads. Decision Sciences, 36(3), 365-396.

Schläfke, M., Silvi, R., \& Möller, K. (2013). A framework for business analytics in performance management. International Journal of Productivity and Performance Management, 62(1), 110-122. doi:10.1108/01443570710763778

\subsection{6/mare.2000.0135}

Schroeck, M., Shockley, R., Smart, J., Romero-Morales, D., \& Tufano, P. P. (2012). Analytics: The realworld use of big data. Retrieved from NY, USA:

Setia, P., Venkatesh, V., \& Joglekar, S. (2013). Leveraging digital technologies: How information quality leads to localized capabilities and customer service performance. MIS Quarterly, $37(2), 565-590$. 
Shanks, G., Bekmamedov, N., \& Sharma, R. (2011). Creating value from business analytics systems: A process-oriented theoretical framework and case study.

Shanks, G., \& Bekmamedova, N. (2012). Achieving benefits with business analytics systems: An evolutionary process perspective. Journal of Decision Systems, 21(3), 231-244.

Sharma, R., Mithas, S., \& Kankanhalli, A. (2014). Transforming decision-making processes: a research agenda for understanding the impact of business analytics on organisations. Eur J Inf Syst, 23(4), 433-441. doi:10.1057/ejis.2014.17

Smith, L., Ng, I., \& Maull, R. (2012). The three value proposition cycles of equipment-based service. Production Planning \& Control, 23(7), 553-570. doi:10.1080/09537287.2011.640055

Spreng, R. A., MacKenzie, S. B., \& Olshavsky, R. W. (1996). A reexamination of the determinants of consumer satisfaction. the Journal of Marketing, 15-32.

Srinivasan, U., \& Arunasalam, B. (2013). Leveraging Big Data Analytics to Reduce Healthcare Costs.

Sun, H., \& Zhang, P. (2008). An exploration of affective factors and their roles in user technology acceptance: Mediation and causality. Journal of the American Society for Information Science and Technology (JASIST), 59(8), 1252-1263.

Tenenhaus, M., Vinzi, V. E., Chatelin, Y. M., \& Lauro, C. (2005). PLS path modeling. Computational Statistics \& Data Analysis, 48(1), 159-205.

Tippins, M. J., \& Sohi, R. S. (2003). IT competency and firm performance: is organizational learning a missing link? Strategic Management Journal, 24(8), 745-761. doi:10.1002/smj.337

Vance, A., Elie-Dit-Cosaque, C., \& Straub, D. W. (2008). Examining trust in information technology artifacts: the effects of system quality and culture. Journal of Management Information Systems, 24(4), 73-100.

Verbraken, T., Lessmann, S., \& Baesens B. (2012). Toward Profit-Driven Churn Modeling with Predictive Marketing Analytics. Paper presented at the Proceedings of the 11th Workshop on e-Business (WEB'2012), Orlando, FL, USA.

Viswanath, V., James, Y. L. T., \& Xin, X. (2012). Consumer acceptance and use of information technology: extending the unified theory of acceptance and use of technology. MIS Quarterly, 36(1), 157-178.

Wixom, B. H., \& Todd, P. A. (2005). A theoretical integration of user satisfaction and technology acceptance. Information Systems Research, 16(1), 85-102.

Wixom, B. H., Yen, B., \& Relich, M. (2013). Maximizing value from business analytics. MIS Quarterly Executive, 12, 111-123.

Xia, Y., \& Zhang, G. P. (2010). The Impact of the Online Channel on Retailers' Performances: An Empirical Evaluation. Decision Sciences, 41(3), 517-546.

Xu, D., Benbasat, I., \& Cenfetelli, R. T. (2013). Integrating Service Quality with System and Information Quality: An Empirical Test in the E-Service Context. MIS Quarterly, 37(3), 777794.

Zeithaml, V. A. (2000). Service quality, profitability, and the economic worth of customers: what we know and what we need to learn. Journal of the Academy of Marketing Science, 28(1), 67-85.

Zhou, T., Lu, Y., \& Wang, B. (2009). The relative importance of website design quality and service quality in determining consumers' online repurchase behavior. Information Systems Management, 26(4), 327-337.

Zviran, M., \& Erlich, Z. (2003). Measuring IS user satisfaction: review and implications. Communications of the Association for Information Systems, 12(1), 5. 


\section{Figures}

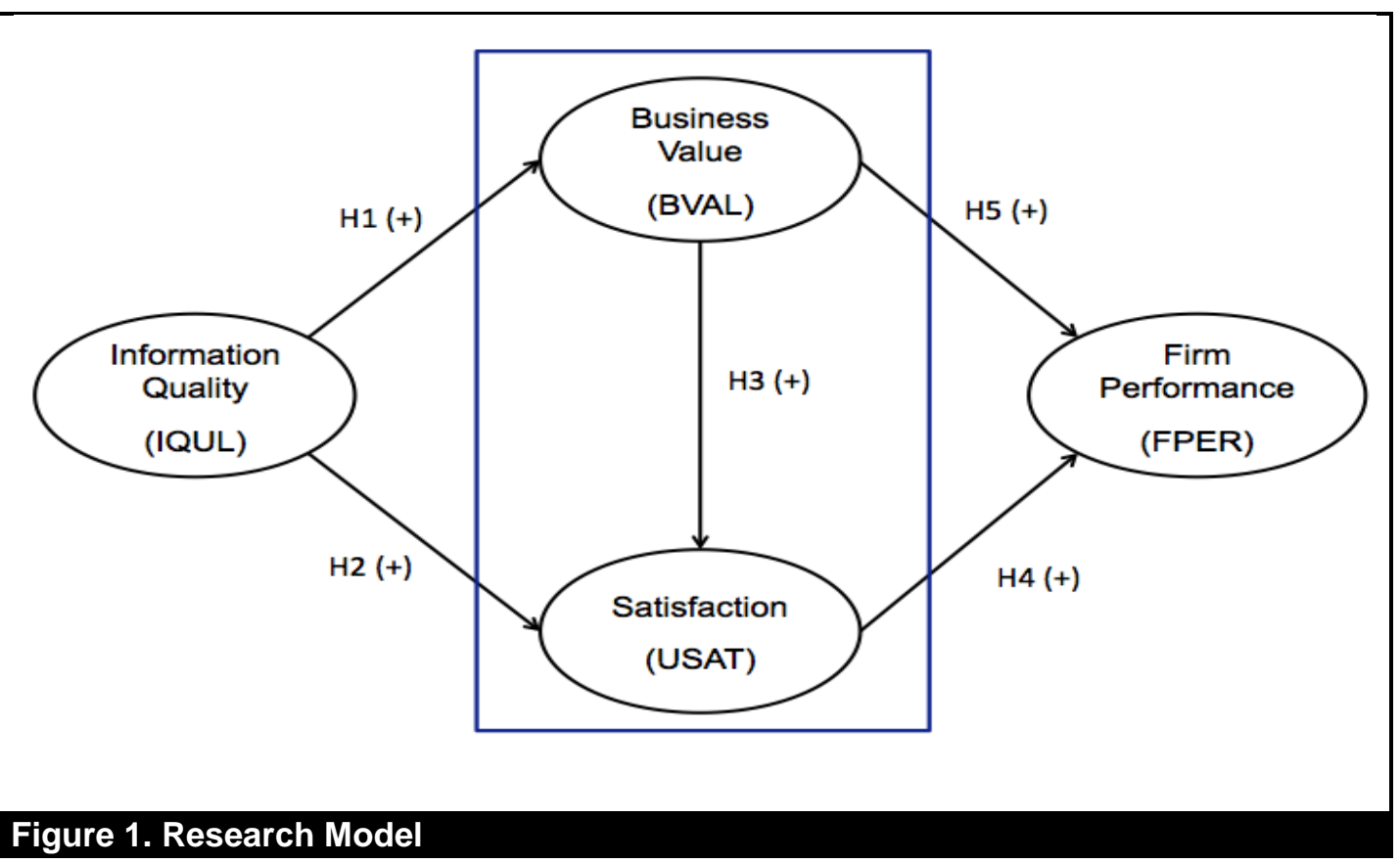




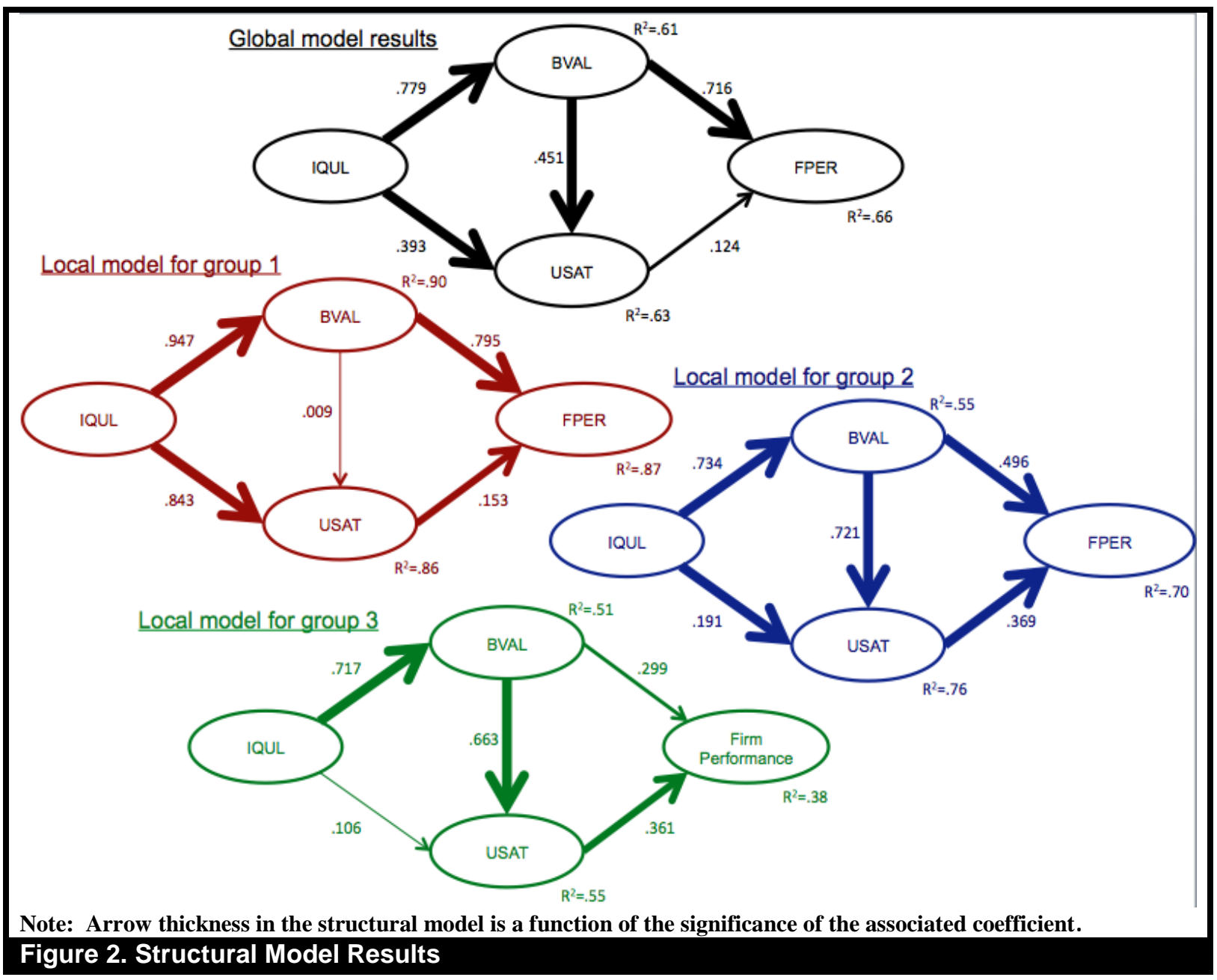

\section{$\underline{\text { Tables }}$}

\section{Table 1. Constructs and Definitions}

\section{Construct and Definition}

Information quality is defined as the completeness, accuracy, format, and currency of information produced by BDA. Completeness indicates the extent to which the user perceives that BDA provide all the necessary information; accuracy focuses on the perceived correctness of information; format refers to the perception of how well the information is presented; and, finally, currency refers to the user's perception of the extent to which the information is up to date.

Business value is defined as the transactional, strategic, and transformational value of BDA. Transactional value refers to the degree to which the user perceives that BDA provide operational benefits, e.g., cost reductions: strategic value refers to the degree of perceived benefits to the organization at a strategic level, e.g., competitive advantage; and, finally, transformational value refers to the degree of perceived changes in the structure and capacity of a firm as a result of BDA, which serve as a catalyst for future benefits.

Satisfaction refers to users' feelings about (or affect from) BDA use.
Source

(Barbara H Wixom \& Todd, 2005)

(Gregor et al., 2006)

(Spreng et al., 1996) 
Firm performance refers to the firm's ability to gain and retain customers; and to improve sales, profitability, and return on investment (ROI).
(S. Mithas, Ramasubbu, \& Sambamurthy, 2011; Tippins \& Sohi, 2003)

\section{Table 2. Business Value of Big Data Analytics}

\begin{tabular}{|c|c|c|c|}
\hline Study & Decision Functions & Business Value & $\operatorname{Firm}(\mathbf{s})$ \\
\hline \multirow[t]{6}{*}{$\begin{array}{l}\text { Davenport } \\
(2006)\end{array}$} & $\begin{array}{l}\text { Customer selection, } \\
\text { loyalty, and service }\end{array}$ & $\begin{array}{l}\text { Identify customers with the greatest } \\
\text { profit potential, loyalty, and service. } \\
\text { Increase likelihood that they will want } \\
\text { the product or service offering, retain } \\
\text { their loyalty. }\end{array}$ & $\begin{array}{l}\text { Harrah's, Capital } \\
\text { One, Barclays }\end{array}$ \\
\hline & Pricing & $\begin{array}{l}\text { Identify the price that will maximize } \\
\text { yield or profit. }\end{array}$ & $\begin{array}{l}\text { Progressive, } \\
\text { Marriott }\end{array}$ \\
\hline & $\begin{array}{l}\text { Product or service } \\
\text { quality }\end{array}$ & $\begin{array}{l}\text { Detect quality problems early and } \\
\text { minimize them. }\end{array}$ & Honda, Intel \\
\hline & Promotion & $\begin{array}{l}\text { Fine-tuning of global promotions for } \\
\text { every medium in every region }\end{array}$ & Dell (DDB matrix) \\
\hline & $\begin{array}{l}\text { Sales, consumer } \\
\text { research, and } \\
\text { marketing }\end{array}$ & $\begin{array}{l}\text { Analysts from functions such as } \\
\text { operations, supply chain, sales, } \\
\text { consumer research, and marketing to } \\
\text { improve total business performance by } \\
\text { analyzing interrelationships among } \\
\text { functional areas. }\end{array}$ & $\begin{array}{l}\text { Procter \& Gamble } \\
(\mathrm{P} \& \mathrm{G})\end{array}$ \\
\hline & Customer defection & $\begin{array}{l}\text { Customer Intelligence Group examines } \\
\text { usage patterns and complaints data to } \\
\text { accurately predict customer defections. }\end{array}$ & $\begin{array}{l}\text { United Parcel } \\
\text { Service (UPS) }\end{array}$ \\
\hline
\end{tabular}




\begin{tabular}{|l|l|l|l|}
\hline $\begin{array}{l}\text { (T. H. Davenport } \\
\text { et al., 2012) }\end{array}$ & Pricing & $\begin{array}{l}\text { Optimize pricing of 73 million items in } \\
\text { just over one hour. }\end{array}$ & Macys.com \\
\hline $\begin{array}{l}\text { Schroeck et al. } \\
(2012)\end{array}$ & Pricing & $\begin{array}{l}\text { Scheduling price reductions to sell } \\
\text { perishable products before they spoil. }\end{array}$ & $\begin{array}{l}\text { Automercados } \\
\text { Plaza's }\end{array}$ \\
\hline $\begin{array}{l}\text { Davenport et al. } \\
(2007)\end{array}$ & Pricing & $\begin{array}{l}\text { Deriving the most accurate pricing of } \\
\text { products and services with precise } \\
\text { calculation of customer profitability. }\end{array}$ & $\begin{array}{l}\text { Royal Bank of } \\
\text { Canada }\end{array}$ \\
\cline { 2 - 5 } & $\begin{array}{l}\text { Customer choice } \\
\text { preferences and } \\
\text { product offerings }\end{array}$ & $\begin{array}{l}\text { Analyze customer choice and customer } \\
\text { feedback from over one billion } \\
\text { reviews. }\end{array}$ & Netflix \\
\hline $\begin{array}{l}\text { Kiron et al. } \\
(2012)\end{array}$ & Service innovation & $\begin{array}{l}\text { Use personal profile and psychology- } \\
\text { based analytics to help people connect } \\
\text { and fall into a loving relationship. }\end{array}$ & Match.com \\
\cline { 2 - 5 } & $\begin{array}{l}\text { New product } \\
\text { development }\end{array}$ & $\begin{array}{l}\text { Each new PayPal initiative across } \\
\text { finance, operations, and products is } \\
\text { examined with quantified impact and } \\
\text { leveraging analytics. }\end{array}$ & PayPal \\
\hline $\begin{array}{l}\text { LaValle et al. } \\
(2011)\end{array}$ & $\begin{array}{l}\text { Data-driven customer } \\
\text { insights }\end{array}$ & $\begin{array}{l}\text { Collected 80\% to 90\% of possibly } \\
\text { needed information about customers to } \\
\text { generate analytics-driven customer } \\
\text { insights. }\end{array}$ & Best Buy \\
\hline
\end{tabular}

\begin{tabular}{|c|c|c|c|}
\hline Study & Decision Functions & Business Value & Firm(s) \\
\hline \multirow[t]{5}{*}{$\begin{array}{l}\text { Manyika et al. } \\
\text { (2011) }\end{array}$} & Market share analysis & $\begin{array}{l}\text { Uses big data to capture market } \\
\text { share from its local competitors. }\end{array}$ & Tesco \\
\hline & $\begin{array}{l}\text { Direct marketing through } \\
\text { recommendation, } \\
\text { relationship marketing }\end{array}$ & $\begin{array}{l}\text { Recommendation engine to } \\
\text { generate "you might also want" } \\
\text { prompts to generate sales. }\end{array}$ & Amazon.com \\
\hline & $\begin{array}{l}\text { Customer behavior, } \\
\text { customer segmentation, } \\
\text { customer profitability }\end{array}$ & $\begin{array}{l}\text { Developed behavioral } \\
\text { segmentation and a multi-tier } \\
\text { membership reward program by } \\
\text { analyzing customer profile, real- } \\
\text { time changes in customer } \\
\text { behavior, and customer } \\
\text { profitability. }\end{array}$ & Neiman Marcus \\
\hline & Email marketing & $\begin{array}{l}\text { Integrated customer databases } \\
\text { with information on some } \\
60 \text { million households to } \\
\text { improve response rate of email } \\
\text { marketing. }\end{array}$ & $\begin{array}{l}\text { Williams- } \\
\text { Sonoma }\end{array}$ \\
\hline & $\begin{array}{l}\text { Customize service offerings, } \\
\text { customer loyalty }\end{array}$ & $\begin{array}{l}\text { Compiled holistic customer } \\
\text { profiles in detail, and conduct }\end{array}$ & $\begin{array}{l}\text { Harrah's, } \\
\text { Progressive }\end{array}$ \\
\hline
\end{tabular}




\begin{tabular}{|c|c|c|c|}
\hline & & $\begin{array}{l}\text { experiments and segment their } \\
\text { customers systematically and } \\
\text { effectively to personalize } \\
\text { product offers and increase } \\
\text { customer loyalty. }\end{array}$ & $\begin{array}{l}\text { Insurance, } \\
\text { Capital One }\end{array}$ \\
\hline \multirow[t]{2}{*}{$\begin{array}{l}\text { Chandrasekaran et } \\
\text { al. (2013) }\end{array}$} & $\begin{array}{l}\text { Customer segmentation, } \\
\text { customer loyalty }\end{array}$ & $\begin{array}{l}\text { Systematically integrates } \\
\text { analytics and consumer insights } \\
\text { using data from its Clubcard } \\
\text { loyalty program to better } \\
\text { segment and target customer } \\
\text { occasions. }\end{array}$ & Tesco \\
\hline & New product acceptance rate & $\begin{array}{l}\text { Simulate new products placed } \\
\text { on shelves in order to test design } \\
\text { effects internally and with } \\
\text { consumers to enhance product } \\
\text { acceptability after launching. }\end{array}$ & $\begin{array}{l}\text { Procter \& } \\
\text { Gamble }(\mathrm{P} \& \mathrm{G})\end{array}$ \\
\hline \multirow[t]{2}{*}{$\begin{array}{l}\text { Davenport and } \\
\text { Patil (2012) }\end{array}$} & $\begin{array}{l}\text { (a) core search } \\
\text { (b) advertisements }\end{array}$ & $\begin{array}{l}\text { Google uses data scientists to } \\
\text { refine its core search and ad- } \\
\text { serving algorithms. }\end{array}$ & Google \\
\hline & $\begin{array}{l}\text { Product, feature (e.g., } \\
\text { 'People you may know') and } \\
\text { value-adding service. }\end{array}$ & $\begin{array}{l}\text { To generate ideas for products, } \\
\text { features, and value-adding } \\
\text { services. By using 'People you } \\
\text { may know', they generated } \\
\text { millions of new page views } \\
\text { which resulted in LinkedIn's } \\
\text { growth trajectory shifting } \\
\text { significantly upward. }\end{array}$ & LinkedIn \\
\hline Liebowitz (2013) & Product management & $\begin{array}{l}\text { Macy's analyze data at stock- } \\
\text { keeping unit (SKU) level to } \\
\text { make sure of the ready } \\
\text { availability of product } \\
\text { assortments. }\end{array}$ & Macys.com \\
\hline
\end{tabular}

\begin{tabular}{|c|c|c|c|c|}
\hline $\begin{array}{l}\text { 2nd-order } \\
\text { constructs }\end{array}$ & $\begin{array}{l}\text { 1st-order } \\
\text { constructs }\end{array}$ & Type & $\begin{array}{l}\text { Item } \\
\text { labels }\end{array}$ & Items \\
\hline \multirow{12}{*}{$\begin{array}{l}\text { Information } \\
\text { quality }\end{array}$} & \multirow{3}{*}{ Completeness } & Reflective & INFQ1 & $\begin{array}{l}\text { The business analytics used: } \\
\text { provide a complete set of information. }\end{array}$ \\
\hline & & Reflective & INFQ2 & produce comprehensive information. \\
\hline & & Reflective & INFQ3 & provide all the information needed. \\
\hline & \multirow{3}{*}{ Currency } & Reflective & INFQ4 & provide the most recent information. \\
\hline & & Reflective & INFQ5 & produce the most current information. \\
\hline & & Reflective & INFQ6 & always provide up-to-date information. \\
\hline & \multirow{3}{*}{ Format } & Reflective & INFQ7 & $\begin{array}{l}\text { The information provided by the analytics is __ well } \\
\text { formatted. }\end{array}$ \\
\hline & & Reflective & INFQ8 & The information provided by the analytics is __ well laid out. \\
\hline & & Reflective & INFQ9 & $\begin{array}{l}\text { The information provided by the analytics is __ clearly } \\
\text { presented on the screen. }\end{array}$ \\
\hline & \multirow{3}{*}{ Accuracy } & Reflective & INFQ10 & $\begin{array}{l}\text { The business analytics used: } \\
\text { produce correct information. }\end{array}$ \\
\hline & & Reflective & INFQ11 & provide few errors in the information. \\
\hline & & Reflective & INFQ12 & provide accurate information. \\
\hline
\end{tabular}




\begin{tabular}{|c|c|c|c|c|}
\hline \multirow{17}{*}{$\begin{array}{l}\text { Business } \\
\text { value } \\
\text { (Gregor et } \\
\text { al., 2006) }\end{array}$} & \multirow{6}{*}{ Transactional } & Reflective & BVTN1 & Savings in supply chain management. \\
\hline & & Reflective & BVTN2 & Reducing operating costs. \\
\hline & & Reflective & BVTN3 & Reducing communication costs. \\
\hline & & Reflective & BVTN4 & Avoiding the need to increase the workforce. \\
\hline & & Reflective & BVTN5 & Increasing return on financial assets. \\
\hline & & Reflective & BVTN6 & Enhancing employee productivity. \\
\hline & \multirow{6}{*}{ Strategic } & Reflective & BVST1 & Creating competitive advantage. \\
\hline & & Reflective & BVST2 & Aligning analytics with business strategy. \\
\hline & & Reflective & BVST3 & Establishing useful links with other organizations. \\
\hline & & Reflective & BVST4 & Enabling quicker response to change. \\
\hline & & Reflective & BVST5 & Improving customer relations. \\
\hline & & Reflective & BVST6 & Providing better products or services to customers. \\
\hline & \multirow{5}{*}{$\begin{array}{l}\text { Transformationa } \\
1\end{array}$} & Reflective & BVTR1 & An improved skill level for employees. \\
\hline & & Reflective & BVTR2 & Developing new business plans. \\
\hline & & Reflective & BVTR3 & Expanding organizational capabilities. \\
\hline & & Reflective & BVTR4 & Improving business models. \\
\hline & & Reflective & BVTR5 & Improving organizational structure/processes. \\
\hline \multirow{4}{*}{ NA } & \multirow{4}{*}{$\begin{array}{l}\text { Satisfaction } \\
\text { (Spreng et al., } \\
\text { 1996) }\end{array}$} & Reflective & SABA1 & $\begin{array}{l}\text { Overall, I am : } \\
\quad \text { satisfied with business analytics. }\end{array}$ \\
\hline & & Reflective & SABA2 & contented with business analytics. \\
\hline & & Reflective & SABA3 & _ pleased with business analytics. \\
\hline & & Reflective & SABA4 & __ delighted with business analytics. \\
\hline \multirow{3}{*}{ NA } & \multirow{3}{*}{$\begin{array}{l}\text { Firm } \\
\text { performance } \\
\text { (Tippins \& } \\
\text { Sohi, 2003) }\end{array}$} & Reflective & FPBA1 & $\begin{array}{l}\text { Using analytics improved __ during the last } 2 \text { years relative to } \\
\text { competitors. } \\
\quad \text { Customer retention }\end{array}$ \\
\hline & & Reflective & FPBA2 & Sales growth \\
\hline & & Reflective & FPBA3 & Profitability \\
\hline
\end{tabular}

\begin{tabular}{|c|c|c|c|c|c|c|c|c|c|c|}
\hline \multirow{2}{*}{$\begin{array}{l}\text { 2nd- } \\
\text { order } \\
\text { LVs }\end{array}$} & \multirow{2}{*}{ 1st-order LVs } & \multirow{2}{*}{ Items } & \multicolumn{4}{|c|}{ Standardized loadings } & \multicolumn{4}{|c|}{ Composite reliability and AVE } \\
\hline & & & Global & G1 & G2 & G3 & Global & G1 & G2 & G3 \\
\hline \multirow{11}{*}{ IQUL } & \multirow{3}{*}{ Completeness } & INFQ1 & 0.932 & 0.975 & 0.901 & 0.927 & \multirow{3}{*}{$\begin{array}{l}\text { CR: } \\
.939 \\
\text { AVE: } \\
.838\end{array}$} & \multirow{3}{*}{$\begin{array}{l}\text { CR: } \\
.960 \\
\text { AVE: } \\
.925\end{array}$} & \multirow{3}{*}{$\begin{array}{l}\text { CR: } \\
.916 \\
\text { AVE: } \\
.784\end{array}$} & \multirow{3}{*}{$\begin{array}{c}\text { CR: } \\
.935 \\
\text { AVE: } \\
.827\end{array}$} \\
\hline & & INFQ2 & 0.942 & 0.966 & 0.928 & 0.933 & & & & \\
\hline & & INFQ3 & 0.871 & 0.945 & 0.824 & 0.866 & & & & \\
\hline & \multirow{3}{*}{ Currency } & INFQ4 & 0.915 & 0.970 & 0.889 & 0.903 & \multirow{3}{*}{$\begin{array}{l}\text { CR: } \\
.934 \\
\text { AVE: } \\
.825\end{array}$} & \multirow{3}{*}{$\begin{array}{l}\text { CR: } \\
.973 \\
\text { AVE: } \\
.949\end{array}$} & \multirow{3}{*}{$\begin{array}{l}\text { CR: } \\
.886 \\
\text { AVE: } \\
.723\end{array}$} & \multirow{3}{*}{$\begin{array}{c}\text { CR: } \\
.930 \\
\text { AVE } \\
.816\end{array}$} \\
\hline & & INFQ5 & 0.870 & 0.977 & 0.744 & 0.873 & & & & \\
\hline & & INFQ6 & 0.940 & 0.976 & 0.908 & 0.932 & & & & \\
\hline & \multirow{3}{*}{ Format } & INFQ7 & 0.953 & 0.979 & 0.941 & 0.947 & \multirow{3}{*}{$\begin{array}{c}\text { CR: } \\
.969 \\
\text { AVE: } \\
.913\end{array}$} & \multirow{3}{*}{$\begin{array}{c}\text { CR: } \\
.977 \\
\text { AVE: } \\
.956 \\
\end{array}$} & \multirow{3}{*}{$\begin{array}{l}\text { CR: } \\
.965 \\
\text { AVE: } \\
.902 \\
\end{array}$} & \multirow{3}{*}{$\begin{array}{c}\text { CR: } \\
.962 \\
\text { AVE: } \\
.894 \\
\end{array}$} \\
\hline & & INFQ8 & 0.966 & 0.979 & 0.957 & 0.966 & & & & \\
\hline & & INFQ9 & 0.948 & 0.975 & 0.950 & 0.924 & & & & \\
\hline & \multirow{2}{*}{ Accuracy } & INFQ10 & 0.947 & 0.980 & 0.931 & 0.935 & \multirow{2}{*}{$\begin{array}{l}\text { CR: } \\
.957\end{array}$} & \multirow{2}{*}{$\begin{array}{l}\text { CR: } \\
.974\end{array}$} & \multirow{2}{*}{$\begin{array}{l}\text { CR: } \\
.940\end{array}$} & \multirow{2}{*}{$\begin{array}{l}\text { CR: } \\
.950\end{array}$} \\
\hline & & INFQ11 & 0.937 & 0.978 & 0.904 & 0.932 & & & & \\
\hline
\end{tabular}




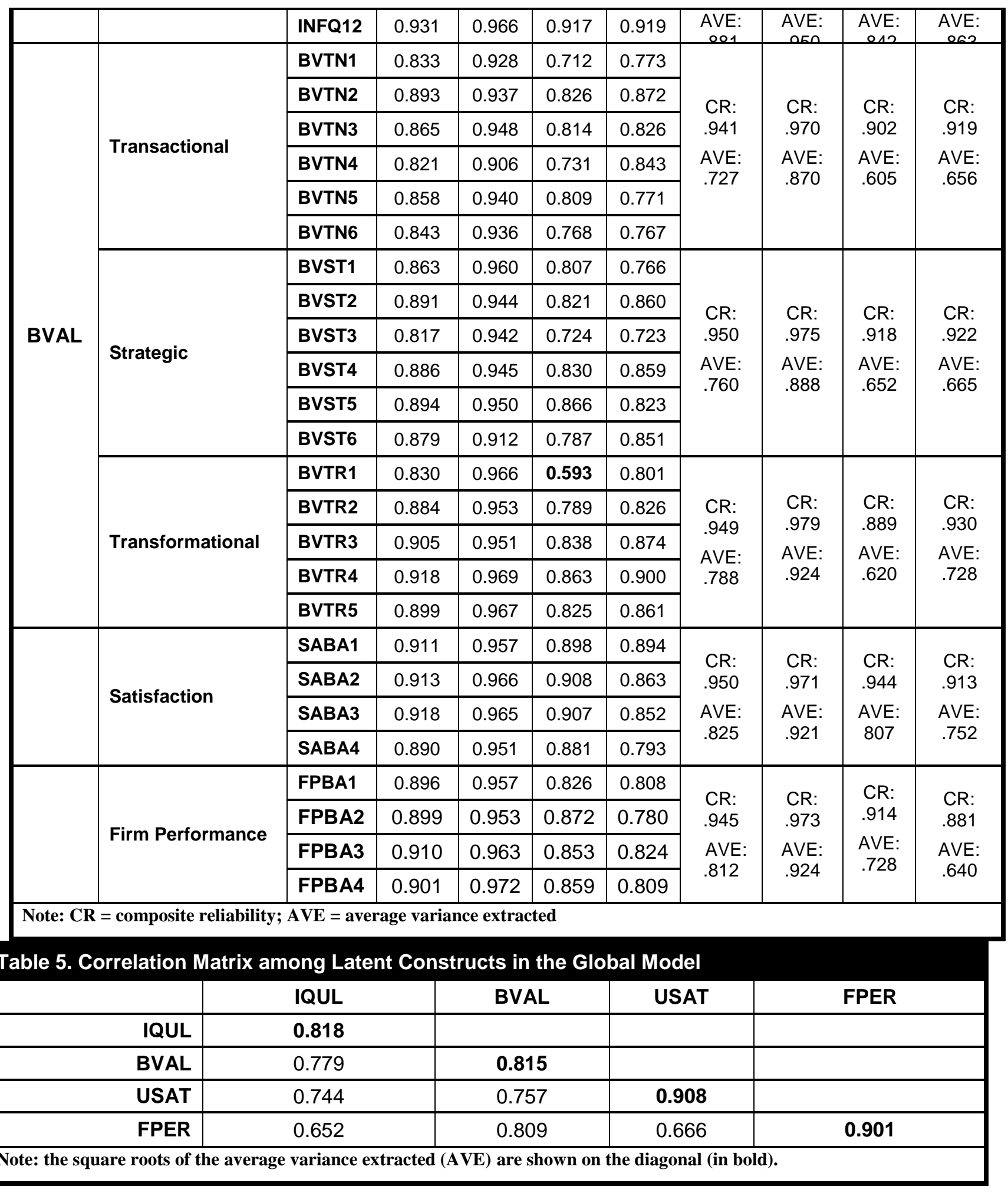

\section{Table 6. Correlation Matrix among Latent Constructs in the Local Model for G1}

\begin{tabular}{|r|c|c|c|c|}
\hline & IQUL & BVAL & USAT & FPER \\
\hline IQUL & $\mathbf{0 . 9 4 8}$ & & & \\
\hline BVAL & 0.947 & $\mathbf{0 . 9 2 4}$ & & \\
\hline USAT & 0.929 & 0.889 & $\mathbf{0 . 9 6 0}$ & \\
\hline FPER & 0.922 & 0.931 & 0.860 & $\mathbf{0 . 9 6 1}$ \\
\hline
\end{tabular}


Note: the square roots of the average variance extracted (AVE) are shown on the diagonal (in bold).

\section{Table 9. Structural Model Results}

\begin{tabular}{|c|c|c|c|c|c|c|c|c|c|c|c|c|c|}
\hline \multirow{2}{*}{$\begin{array}{l}\text { Dependent } \\
\text { :onstructs }\end{array}$} & \multirow{2}{*}{ Structural Paths } & \multicolumn{4}{|c|}{ Standardized path coefficients } & \multicolumn{4}{|c|}{$\mathbf{R}^{2}$ value } & \multicolumn{4}{|c|}{ Contribution to $\mathbf{R}^{2}(\%)$ and $\mathbf{R}^{2}$ value } \\
\hline & & Global & G1 & G2 & G3 & Global & G1 & G2 & G3 & Global & G1 & G2 & G3 \\
\hline BVAL & IQUL & $0.779^{* * *}$ & $0.947^{* \star *}$ & $0.734^{* * *}$ & 0.71 & 0.61 & 0.90 & 0.55 & 0.51 & \multicolumn{4}{|c|}{ NA } \\
\hline \multirow{2}{*}{ USAT } & IQUL --> USAT & $0.393^{* * *}$ & $0.843^{* * *}$ & $0.191^{* * *}$ & $0.106^{\text {N.S. }}$ & \multirow{2}{*}{0.63} & \multirow{2}{*}{0.86} & \multirow{2}{*}{0.76} & \multirow{2}{*}{0.55} & 46 & $90.64 \%$ & $18.19 \%$ & $11.21 \%$ \\
\hline & BVAL --> USAT & $0.451^{* * *}$ & $0.009^{\text {N.S. }}$ & $0.721^{* * *}$ & $0.663^{* * *}$ & & & & & $53.81 \%$ & $9.36 \%$ & $81.82 \%$ & $88.79 \%$ \\
\hline \multirow{2}{*}{ FPER } & BVAL --> FPERF & $0.716^{\star * *}$ & $0.795^{\star \star \star}$ & $0.496^{* * *}$ & $0.299^{*}$ & \multirow{2}{*}{0.66} & \multirow{2}{*}{0.87} & \multirow{2}{*}{0.70} & \multirow{2}{*}{0.38} & $87.51 \%$ & $84.94 \%$ & $57.88 \%$ & $44.58 \%$ \\
\hline & USAT --> FPER & $0.124^{*}$ & $0.153^{* *}$ & $0.369^{* * *}$ & $0.361^{* *}$ & & & & & $12.49 \%$ & $15.06 \%$ & $42.12 \%$ & $55.42 \%$ \\
\hline
\end{tabular}

Note: ${ }^{* * *}$ P-value $<0.001 ;{ }^{* *}$ P-value $<0.01$; ${ }^{*}$ P-value $<0.05$; ${ }^{\text {N.S. }}$ not significant.

Table 7. Correlation Matrix among Latent Constructs in the Local Model for G2

\begin{tabular}{|r|l|l|l|l|}
\hline & IQUL & BVAL & USAT & FPER \\
\hline IQUL & $\mathbf{0 . 7 7 0}$ & & & \\
\hline BVAL & 0.734 & $\mathbf{0 . 7 1 3}$ & & \\
\hline USAT & 0.721 & 0.861 & $\mathbf{0 . 8 9 8}$ & \\
\hline FPER & 0.676 & 0.813 & 0.796 & $\mathbf{0 . 8 5 3}$ \\
\hline
\end{tabular}

Note: the square roots of the average variance extracted (AVE) are shown on the diagonal (in bold).

\section{Table 8. Correlation Matrix among Latent Constructs in the Local Model for G3}

\begin{tabular}{|r|l|l|l|l|}
\hline & IQUL & BVAL & USAT & FPER \\
\hline IQUL & $\mathbf{0 . 7 6 5}$ & & & \\
\hline BVAL & 0.717 & $\mathbf{0 . 7 3 6}$ & & \\
\hline USAT & 0.582 & 0.740 & $\mathbf{0 . 8 5 1}$ & \\
\hline FPER & 0.494 & 0.566 & 0.581 & $\mathbf{0 . 8 0 6}$ \\
\hline
\end{tabular}

Note: the square roots of the average variance extracted (AVE) are shown on the diagonal (in bold). 


\begin{tabular}{|c|c|c|c|c|c|c|c|c|c|c|}
\hline \multirow{2}{*}{$\begin{array}{l}\text { 2nd- } \\
\text { order } \\
\text { LVs }\end{array}$} & \multirow[b]{2}{*}{ 1st-order LVs } & \multirow[b]{2}{*}{ Items } & \multicolumn{2}{|c|}{ Overall } & \multicolumn{2}{|c|}{ G1 } & \multicolumn{2}{|c|}{ G2 } & \multicolumn{2}{|c|}{ G3 } \\
\hline & & & Mean & $\begin{array}{l}\text { Std. } \\
\text { Dev. }\end{array}$ & Mean & $\begin{array}{l}\text { Std. } \\
\text { Dev. }\end{array}$ & Mean & $\begin{array}{l}\text { Std. } \\
\text { Dev. }\end{array}$ & Mean & $\begin{array}{l}\text { Std. } \\
\text { Dev. }\end{array}$ \\
\hline \multirow{12}{*}{ IQUL } & \multirow{3}{*}{ Completeness } & INFQ1 & 4.84 & 1.25 & 5.04 & 1.09 & 4.97 & 1.23 & 4.48 & 1.35 \\
\hline & & INFQ2 & 4.85 & 1.21 & 5.07 & 1.12 & 4.93 & 1.25 & 4.55 & 1.22 \\
\hline & & INFQ3 & 4.62 & 1.39 & 5.05 & 1.09 & 4.66 & 1.49 & 4.15 & 1.39 \\
\hline & \multirow{3}{*}{ Currency } & INFQ4 & 5.04 & 1.08 & 4.94 & 1.10 & 5.16 & 1.00 & 5.01 & 1.14 \\
\hline & & INFQ5 & 4.91 & 1.21 & 5.02 & 1.12 & 4.93 & 1.18 & 4.77 & 1.33 \\
\hline & & INFQ6 & 5.04 & 1.16 & 5.01 & 1.19 & 5.18 & 1.03 & 4.93 & 1.24 \\
\hline & \multirow{3}{*}{ Format } & INFQ7 & 5.08 & 1.13 & 4.97 & 1.02 & 5.19 & 1.24 & 5.08 & 1.09 \\
\hline & & INFQ8 & 5.11 & 1.15 & 4.95 & 1.03 & 5.23 & 1.22 & 5.14 & 1.15 \\
\hline & & INFQ9 & 5.03 & 1.26 & 4.95 & 1.09 & 5.13 & 1.35 & 4.99 & 1.29 \\
\hline & \multirow{3}{*}{ Accuracy } & INFQ10 & 5.17 & 1.06 & 4.97 & 1.07 & 5.31 & 1.02 & 5.21 & 1.07 \\
\hline & & INFQ11 & 5.09 & 1.17 & 4.97 & 1.12 & 5.20 & 1.20 & 5.08 & 1.18 \\
\hline & & INFQ12 & 4.99 & 1.22 & 4.90 & 1.14 & 5.12 & 1.31 & 4.95 & 1.18 \\
\hline \multirow{5}{*}{ BVAL } & \multirow{5}{*}{ Transactional } & BVTN1 & 4.70 & 1.15 & 4.83 & 1.08 & 5.10 & 1.04 & 4.11 & 1.11 \\
\hline & & BVTN2 & 4.90 & 1.17 & 5.01 & 1.09 & 5.31 & 0.99 & 4.32 & 1.21 \\
\hline & & BVTN3 & 4.78 & 1.18 & 4.93 & 1.15 & 4.99 & 1.11 & 4.40 & 1.19 \\
\hline & & BVTN4 & 4.71 & 1.24 & 4.86 & 1.06 & 4.96 & 1.37 & 4.27 & 1.12 \\
\hline & & BVTN5 & 4.95 & 1.17 & 4.93 & 1.15 & 5.43 & 0.97 & 4.45 & 1.18 \\
\hline
\end{tabular}




\begin{tabular}{|c|c|c|c|c|c|c|c|c|c|c|}
\hline & & BVTN6 & 4.94 & 1.25 & 4.93 & 1.21 & 5.40 & 1.09 & 4.44 & 1.26 \\
\hline & \multirow{6}{*}{ Strategic } & BVST1 & 5.11 & 1.15 & 4.95 & 1.03 & 5.65 & 0.92 & 4.66 & 1.25 \\
\hline & & BVST2 & 5.12 & 1.11 & 4.92 & 1.08 & 5.62 & 0.84 & 4.77 & 1.21 \\
\hline & & BVST3 & 4.85 & 1.18 & 4.92 & 1.08 & 5.24 & 1.01 & 4.33 & 1.27 \\
\hline & & BVST4 & 5.03 & 1.16 & 4.95 & 1.07 & 5.45 & 1.01 & 4.63 & 1.23 \\
\hline & & BVST5 & 5.03 & 1.21 & 4.87 & 1.08 & 5.66 & 1.04 & 4.50 & 1.22 \\
\hline & & BVST6 & 5.08 & 1.18 & 4.94 & 1.10 & 5.70 & 0.94 & 4.51 & 1.18 \\
\hline & \multirow{5}{*}{ Transformational } & BVTR1 & 4.83 & 1.13 & 5.03 & 1.18 & 5.11 & 1.06 & 4.31 & 0.98 \\
\hline & & BVTR2 & 4.96 & 1.04 & 5.01 & 1.07 & 5.34 & 0.78 & 4.48 & 1.08 \\
\hline & & BVTR3 & 5.01 & 1.12 & 4.92 & 1.18 & 5.47 & 0.90 & 4.58 & 1.11 \\
\hline & & BVTR4 & 5.03 & 1.11 & 4.96 & 1.12 & 5.44 & 0.93 & 4.64 & 1.14 \\
\hline & & BVTR5 & 4.91 & 1.20 & 4.93 & 1.25 & 5.28 & 1.01 & 4.48 & 1.20 \\
\hline \multirow{8}{*}{ N/A } & \multirow{4}{*}{ Satisfaction } & SABA1 & 4.97 & 1.16 & 5.20 & 1.09 & 4.83 & 1.33 & 4.88 & 0.97 \\
\hline & & SABA2 & 4.77 & 1.20 & 5.12 & 1.14 & 4.62 & 1.26 & 4.59 & 1.12 \\
\hline & & SABA3 & 4.92 & 1.11 & 5.18 & 1.13 & 4.85 & 1.17 & 4.73 & 0.97 \\
\hline & & SABA4 & 4.93 & 1.02 & 5.12 & 1.13 & 4.90 & 0.98 & 4.76 & 0.90 \\
\hline & \multirow{4}{*}{$\begin{array}{l}\text { Firm } \\
\text { Performance }\end{array}$} & FPBA1 & 4.78 & 1.22 & 5.03 & 1.01 & 5.35 & 1.11 & 3.89 & 1.02 \\
\hline & & FPBA2 & 4.87 & 1.25 & 5.03 & 1.07 & 5.49 & 1.09 & 4.00 & 1.08 \\
\hline & & FPBA3 & 4.95 & 1.19 & 5.06 & 1.04 & 5.54 & 0.92 & 4.18 & 1.17 \\
\hline & & FPBA4 & 4.89 & 1.22 & 5.08 & 1.06 & 5.38 & 1.00 & 4.15 & 1.24 \\
\hline
\end{tabular}

\section{Table 11. Item Means Comparison among REBUS Groups}

\begin{tabular}{|c|c|c|c|c|c|}
\hline $\begin{array}{c}\text { 2nd-order } \\
\text { LVs }\end{array}$ & 1st-order LVs & Items & G1 vs G2 & G1 vs G3 & G2 vs $\mathrm{G}$ \\
\hline \multirow{12}{*}{ IQUL } & \multirow{3}{*}{ Completeness } & INFQ1 & $0.069^{\text {N.S. }}$ & $0.562^{* *}$ & $0.493^{*}$ \\
\hline & & INFQ2 & $0.146^{\text {N.S. }}$ & $0.519^{* *}$ & $0.374^{\text {N.S. }}$ \\
\hline & & INFQ3 & $0.394^{*}$ & $0.905^{* * *}$ & $0.512^{*}$ \\
\hline & \multirow{3}{*}{ Currency } & INFQ4 & $0.219^{\text {N.S. }}$ & $0.072^{\text {N.S. }}$ & $0.147^{\text {N.S. }}$ \\
\hline & & INFQ5 & $0.094^{\text {N.S. }}$ & $0.250^{\text {N.S. }}$ & $0.155^{\text {N.S. }}$ \\
\hline & & INFQ6 & $0.166^{\text {N.S. }}$ & $0.083^{\text {N.S. }}$ & $0.249^{\text {N.S. }}$ \\
\hline & \multirow{3}{*}{ Format } & INFQ7 & $0.216^{\text {N.S. }}$ & $0.114^{\text {N.S. }}$ & $0.102^{\text {N.S. }}$ \\
\hline & & INFQ8 & $0.283^{\text {N.S. }}$ & $0.186^{\text {N.S. }}$ & $0.096^{\text {N.S. }}$ \\
\hline & & INFQ9 & $0.181^{\text {N.S. }}$ & $0.041^{\text {N.S. }}$ & $0.140^{\text {N.S. }}$ \\
\hline & \multirow{3}{*}{ Accuracy } & INFQ10 & $0.345^{\text {N.S. }}$ & $0.239^{\text {N.S. }}$ & $0.106^{\text {N.S. }}$ \\
\hline & & INFQ11 & $0.234^{\text {N.S. }}$ & $0.114^{\text {N.S. }}$ & $0.120^{\text {N.S. }}$ \\
\hline & & INFQ12 & $0.222^{\text {N.S. }}$ & $0.050^{\text {N.S. }}$ & $0.172^{\text {N.S. }}$ \\
\hline \multirow{6}{*}{ BVAL } & \multirow{6}{*}{ Transactional } & BVTN1 & $0.275^{\text {N.S. }}$ & $0.712^{* * *}$ & $0.987^{* * *}$ \\
\hline & & BVTN2 & $0.295^{\mathrm{NSS}}$ & $0.687^{* * *}$ & $0.983^{* * *}$ \\
\hline & & BVTN3 & $0.062^{\text {N.S. }}$ & $0.533^{* *}$ & $0.595^{* * *}$ \\
\hline & & BVTN4 & $0.106^{\text {N.S. }}$ & $0.586^{* *}$ & $0.692^{* * *}$ \\
\hline & & BVTN5 & $0.497^{* *}$ & $0.481^{* *}$ & $0.978^{* * *}$ \\
\hline & & BVTN6 & $0.470^{*}$ & $0.491^{* *}$ & $0.961^{* * *}$ \\
\hline
\end{tabular}




\begin{tabular}{|c|c|c|c|c|c|}
\hline & \multirow{6}{*}{ Strategic } & BVST1 & $0.699^{* * *}$ & $0.293^{\text {N.S. }}$ & $0.992^{* * *}$ \\
\hline & & BVST2 & $0.702^{* * *}$ & $0.148^{\text {N.S. }}$ & $0.850^{* * *}$ \\
\hline & & BVST3 & $0.322^{\text {N.S. }}$ & $0.585^{* * *}$ & $0.907^{* * *}$ \\
\hline & & BVST4 & $0.505^{* *}$ & $0.324^{\text {N.S. }}$ & $0.829^{* * *}$ \\
\hline & & BVST5 & $0.790^{* * *}$ & $0.367^{\text {N.S. }}$ & $1.157^{* * *}$ \\
\hline & & BVST6 & $0.765^{* * *}$ & $0.428^{* *}$ & $1.193^{* * *}$ \\
\hline & \multirow{5}{*}{ Transformational } & BVTR1 & $0.080^{\text {N.S. }}$ & $0.718^{* * *}$ & $0.799^{* * *}$ \\
\hline & & BVTR2 & $0.332^{*}$ & $0.531^{* * *}$ & $0.863^{* * *}$ \\
\hline & & BVTR3 & $0.554^{* * *}$ & $0.335^{\text {N.S. }}$ & $0.889^{* * *}$ \\
\hline & & BVTR4 & $0.485^{* *}$ & $0.324^{\text {N.S. }}$ & $0.809^{* * *}$ \\
\hline & & BVTR5 & $0.349^{\text {N.S. }}$ & $0.449^{* *}$ & $0.799^{* * *}$ \\
\hline & \multirow{4}{*}{ Satisfaction } & SABA1 & $0.371^{\text {N.S. }}$ & $0.329^{\text {N.S. }}$ & $0.042^{\text {N.S. }}$ \\
\hline & & SABA2 & $0.502^{* *}$ & $0.529^{* *}$ & $0.027^{\text {N.S. }}$ \\
\hline & & SABA3 & $0.332^{\text {N.S. }}$ & $0.455^{*}$ & $0.123^{\text {N.S. }}$ \\
\hline & & SABA4 & $0.224^{\text {N.S. }}$ & $0.362^{*}$ & $0.138^{\text {N.S. }}$ \\
\hline & \multirow{4}{*}{$\begin{array}{l}\text { Firm } \\
\text { Performance }\end{array}$} & FPBA1 & $0.321^{*}$ & $1.145^{* * *}$ & $1.466^{* * *}$ \\
\hline & & FPBA2 & $0.460^{* *}$ & $1.031^{* * *}$ & $1.491^{* * *}$ \\
\hline & & FPBA3 & $0.471^{* *}$ & $0.884^{* * *}$ & $1.360^{* * *}$ \\
\hline & & FPBA4 & $0.298^{\text {N.S. }}$ & $0.936^{* * *}$ & $1.234^{* * *}$ \\
\hline
\end{tabular}

Table 12. Construct Means and Standard Deviations

\begin{tabular}{|r|cc|cc|cc|cc|}
\hline \multirow{2}{*}{$\begin{array}{c}\text { 2nd-order } \\
\text { Constructs }\end{array}$} & \multicolumn{2}{|c|}{ Overall } & \multicolumn{2}{c|}{ G1 } & \multicolumn{2}{c|}{ G2 } & \multicolumn{2}{c|}{ G3 } \\
\cline { 2 - 10 } & Mean & Std. Dev. & Mean & Std. Dev. & Mean & Std. Dev. & Mean & Std. Dev. \\
\hline IQUL & 4.99 & 0.97 & 4.99 & 1.04 & 5.09 & 0.94 & 4.87 & 0.93 \\
\hline BVAL & 4.94 & 0.95 & 4.93 & 1.03 & 5.38 & 0.71 & 4.47 & 0.87 \\
\hline USAT & 4.90 & 1.02 & 5.16 & 1.07 & 4.80 & 1.07 & 4.74 & 0.85 \\
\hline FPER & 4.87 & 1.10 & 5.05 & 1.01 & 5.44 & 0.88 & 4.05 & 0.91 \\
\hline
\end{tabular}

Table 13. Construct Means Comparison among REBUS Groups

\begin{tabular}{|c|c|c|c|c|}
\hline Mean Comparison & IQUL & BVAL & USAT & FPER \\
\hline G1 vs G2 & $0.104^{\text {N.S. }}$ & $0.442^{* * *}$ & $0.359^{*}$ & $0.386^{* *}$ \\
\hline G1 vs G3 & $0.133^{\text {N.S. }}$ & $0.459^{* * *}$ & $0.416^{*}$ & $0.998^{* * t}$ \\
\hline G2 vs G3 & $0.216^{\text {N.S. }}$ & $0.902^{* * *}$ & $0.057^{\text {N.S. }}$ & $1.384^{* * *}$ \\
\hline
\end{tabular}

Table 14. Structural Model Comparison among REBUS Groups

\begin{tabular}{|c|c|cc|cc|}
\hline \multirow{2}{*}{$\begin{array}{c}\text { Path } \\
\text { coefficient } \\
\text { comparison }\end{array}$} & BVAL & \multicolumn{2}{|c|}{ USAT } & \multicolumn{2}{c|}{ FPER } \\
\cline { 2 - 6 } & IQUL --> BVAL & IQUL -> USAT & BVAL -> USAT & BVAL --> FPER & USAT --> FPER \\
\hline
\end{tabular}




\begin{tabular}{|c|c|c|c|c|c|}
\hline G1 vs G2 & $0.383^{\text {** }}$ & $0.669^{* *}$ & $1.007^{* *}$ & $0.179^{\text {N.S. }}$ & $0.173^{\text {N.S. }}$ \\
\hline G1 vs G3 & $0.272^{* \star}$ & $0.779^{* *}$ & $0.562^{*}$ & $0.455^{* *}$ & $0.238^{\text {N.S. }}$ \\
\hline G2 vs G3 & $0.111^{\text {N.S. }}$ & $0.110^{\text {N.S. }}$ & $0.445^{*}$ & $0.276^{\star \star}$ & $0.066^{\text {N.S. }}$ \\
\hline
\end{tabular}




\begin{tabular}{|c|c|c|c|c|c|}
\hline \multirow[b]{2}{*}{ Variable } & \multirow[b]{2}{*}{ Categories } & \multicolumn{4}{|c|}{ Relative frequency per category (\%) } \\
\hline & & $\begin{array}{c}\text { Global } \\
n=302\end{array}$ & $\begin{array}{c}\mathrm{G} 1 \\
\mathrm{n}_{1}=98\end{array}$ & $\begin{array}{c}\text { G2 } \\
\mathrm{n}_{2}=108\end{array}$ & $\begin{array}{c}\text { G3 } \\
n_{3}=96\end{array}$ \\
\hline \multirow{2}{*}{ Country } & France & 49.67 & 53.06 & 53.70 & 41.67 \\
\hline & USA & 50.33 & 46.94 & 46.30 & 58.33 \\
\hline \multirow{2}{*}{ Gender } & Female & 20.86 & 15.31 & 17.59 & 30.21 \\
\hline & Male & 79.14 & 84.69 & 82.41 & 69.79 \\
\hline \multirow{5}{*}{ Age } & 18 to 25 & 4.31 & 8.16 & 3.70 & 1.04 \\
\hline & 26 to 33 & 17.22 & 23.47 & 12.04 & 16.67 \\
\hline & 34 to 41 & 28.48 & 23.47 & 28.70 & 33.33 \\
\hline & 42 to 49 & 24.17 & 24.49 & 26.85 & 20.83 \\
\hline & 50 or more & 25.83 & 20.41 & 28.70 & 28.13 \\
\hline \multirow{6}{*}{ Education } & No formal qualification & 0.66 & 1.02 & 0.00 & 1.04 \\
\hline & Primary qualification & 0.66 & 1.02 & 0.93 & 0.00 \\
\hline & Secondary qualification & 5.30 & 4.08 & 6.48 & 5.21 \\
\hline & College qualification & 12.25 & 13.27 & 13.89 & 9.38 \\
\hline & Undergraduate degree & 30.13 & 25.51 & 31.48 & 33.33 \\
\hline & Postgraduate degree & 50.99 & 55.10 & 47.22 & 51.04 \\
\hline \multirow{6}{*}{$\begin{array}{l}\text { Years of } \\
\text { experience }\end{array}$} & Less than one year & 5.96 & 8.16 & 3.70 & 6.25 \\
\hline & $2-5$ years & 32.45 & 35.71 & 27.78 & 34.38 \\
\hline & $6-10$ years & 19.21 & 21.43 & 19.44 & 16.67 \\
\hline & $11-15$ years & 20.86 & 17.35 & 24.07 & 20.83 \\
\hline & $16-20$ years & 9.93 & 11.22 & 11.11 & 7.29 \\
\hline & Over 20 years & 11.59 & 6.12 & 13.89 & 14.58 \\
\hline \multirow{12}{*}{ Firm Size } & 0-19 & 1.33 & 1.02 & 1.85 & 1.04 \\
\hline & $20-99$ & 3.97 & 3.06 & 3.70 & 5.21 \\
\hline & $100-249$ & 5.30 & 4.08 & 5.56 & 6.25 \\
\hline & $250-499$ & 6.29 & 5.10 & 6.48 & 7.29 \\
\hline & $500-999$ & 6.29 & 5.10 & 8.33 & 5.21 \\
\hline & $1,000-2,499$ & 9.27 & 10.20 & 9.26 & 8.33 \\
\hline & $2,500-4,999$ & 9.60 & 9.18 & 12.04 & 7.29 \\
\hline & $5,000-9,999$ & 9.93 & 8.16 & 9.26 & 12.50 \\
\hline & $10,000-24,999$ & 12.58 & 12.25 & 11.11 & 14.58 \\
\hline & $25,000-49,999$ & 5.63 & 3.06 & 5.56 & 8.33 \\
\hline & $50,000-99,999$ & 11.92 & 16.33 & 11.11 & 8.33 \\
\hline & 100,000 or more & 17.88 & 22.45 & 15.74 & 15.63 \\
\hline
\end{tabular}

Note: Value displayed as percentage of total responses. Percentages that are significantly different from the others at level alpha $=\mathbf{0 . 0 5}$ are in bold. 
Table 16. Results of Hypotheses

\begin{tabular}{|l|c|c|c|c|}
\hline \multicolumn{1}{|c|}{ Hypotheses } & \multicolumn{4}{c|}{ Results } \\
\cline { 2 - 5 } & $\begin{array}{c}\text { Global } \\
\text { Model }\end{array}$ & G1 & G2 & G3 \\
\hline $\begin{array}{l}\text { H1: Perceived IQUL has a significant } \\
\text { positive impact on perceived BVAL in BDA. }\end{array}$ & Supported & Supported & Supported & Supported \\
\hline $\begin{array}{l}\text { H2: Perceived IQUL has a significant } \\
\text { positive impact on perceived USAT in BDA. }\end{array}$ & Supported & Supported & Supported & $\begin{array}{c}\text { Not } \\
\text { Supported }\end{array}$ \\
\hline $\begin{array}{l}\text { H3: Perceived BVAL has a significant } \\
\text { positive impact on perceived USAT in BDA. }\end{array}$ & Supported & $\begin{array}{c}\text { Not } \\
\text { supported }\end{array}$ & Supported & Supported \\
\hline $\begin{array}{l}\text { H4: Perceived USAT has a significant } \\
\text { positive impact on perceived FPER in BDA. }\end{array}$ & Supported & Supported & Supported & Supported \\
\hline $\begin{array}{l}\text { H5: Perceived BVAL has a significant } \\
\text { positive impact on perceived FPER in BDA. }\end{array}$ & Supported & Supported & Supported & Supported \\
\hline
\end{tabular}

